U.S. GEOLOGICAL SURVEY CIRCULAR 994

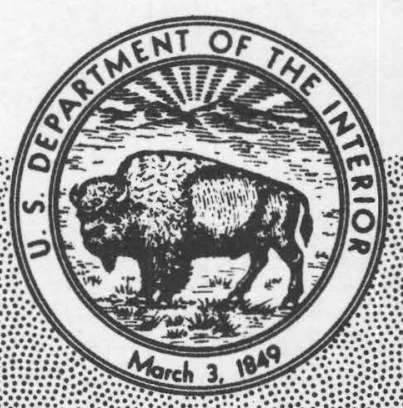

Uranium Resource Assessment by the Geological Survey: Methodology and Plan to Update the National Resource Base 



\section{Uranium Resource Assessment by the Geological Survey: Methodology and Plan to Update the National Resource Base}

By Warren I. Finch and Richard B. McCammon

\section{U.S. GEOLOGICAL SURVEY CIRCULAR 994}

Work done in cooperation with the Energy Information Administration, U.S. Department of Energy

Describes a new method to estimate undiscovered uranium endowment and the plan to conduct assessments necessary for a sound, current resource picture 
Department of the Interior

DONALD PAUL HODEL, Secretary

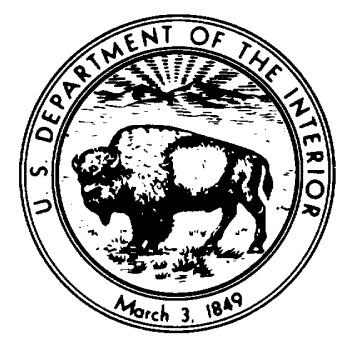

\section{U.S. Geological Survey}

Dallas L. Peck, Director

\section{Library of Congress Cataloging-in-Publication Data}

Finch, Warren Irvin, 1924-

Uranium resource assessment by the Geological Survey.

(U.S. Geological Survey circular ; 994)

Bibliography: $\mathbf{p}$.

Supt. of Docs. no.: I 19.4/2:994

1. Uranium ores-United States. 2. Mine surveying. I. McCammon, Richard B. II. Title. III. Series: Geological Survey circular ; 994.
QE75.C5
no. 994
$557.3 \mathrm{~s}$
86-600418
[TN490.U7]
[553.4'932'0973]

Free on application to the Books and Open-File Reports Section, U.S. Geological Survey Federal Center, Box 25425, Denver, CO 80225 


\section{CONTENTS}

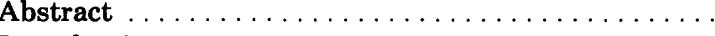

Introduction

Chronology of assessing potential uranium resources

Terminology of resource reporting . . . . . . . .

National uranium resource assessment responsibilities

Purpose of this report $\ldots \ldots \ldots \ldots \ldots \ldots \ldots$

Acknowledgments $\ldots \ldots \ldots \ldots \ldots \ldots \ldots \ldots \ldots$

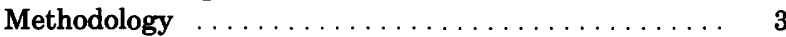

Standard NURE method ..............4 4

Deposit-size-frequency method, a modification of the standard NURE method . . . . . . . . . 5

The assessment procedure $\ldots \ldots \ldots \ldots \ldots \ldots \ldots$

Geologic favorability $\ldots \ldots \ldots \ldots \ldots \ldots \ldots \ldots$

Control area $\ldots \ldots \ldots \ldots \ldots \ldots \ldots \ldots \ldots \ldots$

Development of grade-tonnage distributions for control areas . . . . . . . . . . . . . . . . . .

Development of deposit-size-frequency data . . . . .

Elicitation . . . . . . . . . . . . . . .

Calculation of the estimate
1

1

2

2

2

3

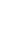

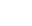

8

Reportingsion $\ldots \ldots \ldots \ldots \ldots \ldots \ldots \ldots \ldots \ldots$

porting of endowment and integration into the National

resource base $\ldots \ldots \ldots \ldots \ldots \ldots \ldots \ldots \ldots \ldots$
Strategy to update the National uranium endowment estimates $\ldots \ldots \ldots \ldots \ldots \ldots \ldots \ldots \ldots \ldots \ldots$

11 International nuclear energy minerals information ... 18

11 References cited .................. 21

11 Appendix A-Memorandum of Understanding . . . . 23

\section{ILLUSTRATIONS}

FIGURE 1. Correlation diagram for uranium resource terminology used by DOE, DOI, and NEA/IAEA ........

2. Comparison of $F$ of the standard NURE method with the $n_{i} / A_{c}$ of the deposit-size-frequency method ...

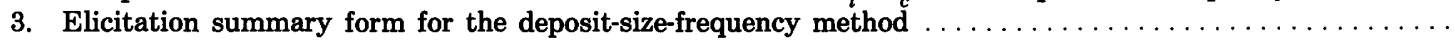

4. Grade-tonnage curves for the Ambrosia Lake control area, New Mexico . . . . . . . . . . . . . . . .

5. Map showing the Colville-Okanogan favorable area and Lake Gillette proto-control area in the Sandpoint and Spokane $2^{\circ}$ NTMS quadrangles, Washington, Idaho, and Montana $\ldots \ldots \ldots \ldots \ldots \ldots$

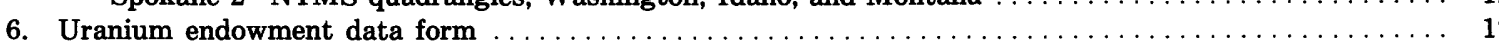

7. Principal surficial uranium deposit terranes in the conterminous United States $\ldots \ldots \ldots \ldots \ldots$

8. Map of the conterminous United States showing A-priority and B-priority quadrangles for uranium endowment estimation

\section{TABLES}

TABLE 1. A list of topics to consider for comparison with available criteria to recognize favorability for uranium . .

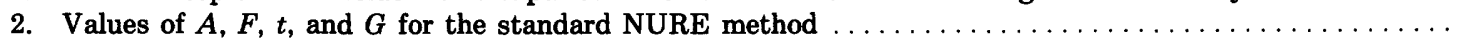

3. Values of $A_{c}$ and size distribution of deposits for the deposit-size-frequency method $\ldots \ldots \ldots \ldots \ldots \ldots$

4. NTMS $2^{\circ}$ quadrangles in conterminous United States selected to be assessed for uranium resources by the

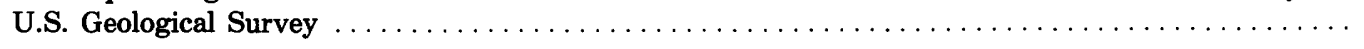


Assessment: the economic evaluation of undiscovered resources. Central moments: values about the mean that are special mathematical expectations useful in describing, and mathematically manipulating, random variables. The first four central moments (the mean, the variance, and the third and fourth moments about the mean) are generally adequate to describe most distributions.

Confidence: belief that the true value of a given variable lies within a stated interval.

Confidence interval: a range of values, between stated upper and lower limits within which an actual measurement is expected to occur with a stated probability.

Confidence limits: the probability values that bound a confidence interval. The lower and upper limits used in this report are 5 percent and 95 percent, respectively.

Control area: a specific geographic area for which the uranium reserves, potential resources, production (if any), and geologic characteristics of uranium concentration are known.

Cutoff grade: the lowest grade of mineralized material, in percent $\mathrm{U}_{3} \mathrm{O}_{8}$, at a minimum specified thickness that can be mined at a specified cost.

Elicitation: the formalized discussion between a principal scientist and a team of experts that leads to an estimate of the undiscovered uranium endowment within a favorable area.

Endowment: [see Uranium endowment.]

Estimated additional resources-Category I (EAR-I, NEA/ IAEA): refers to uranium in addition to reasonably assured resources (RAR) that is expected, mostly on the basis of direct geological evidence, to occur in extensions of well-explored deposits and in deposits in which geological continuity has been established but where specific data and measurements of the deposits and knowledge of their characteristics are considered to be inadequate to classify the resource as RAR.

Estimated additional resources-Category II (EAR-II, NEA IAEA): refers to uranium in addition to EAR-I that is expected to occur in deposits believed to exist in well-defined geological trends or areas of mineralization with known - deposits.

Favorable area: a geographic area in which the available data indicate the existence of geologic environments that were favorable for the concentration of uranium.

Hypothetical resources (DOI): undiscovered resources in deposits that are similar to known uranium deposits and that may reasonably be expected to exist in the same producing district or region under analogous geologic conditions.

Indicated reserves (DOI): reserves whose quantity and grade are calculated from data similar to that of measured reserves but for which data points are less adequately spaced.

Inferred reserves (DOI): reserves whose estimates are based on assumed continuity beyond measured and (or) indicated reserves for which geologic evidence exists.

Mean: the expected value, or the first central moment, of a pro bability distribution.

Measured reserves (DOI): reserves whose quantity is computed from measurements revealed in outcrops, trenches, workings, or drill holes; grade is computed from analyses of closely spaced samples.

Possible potential resources (DOE): estimates of undiscovered or partly defined uranium deposits in rocks or geologic settings productive elsewhere within the same geologic province or subprovince.

Potential resources: the portions of the uranium endowment, in tons of $\mathrm{U}_{3} \mathrm{O}_{8}$, that are estimated to be producible at selected forward costs in dollars per pound of $\mathrm{U}_{3} \mathrm{O}_{8}$.

Probability: a statistical measure, where zero is impossibility and one is certainty, of the likelihood that a given event will occur or that a specific level of a quantifiable variable will be attained or exceeded.

Probable potential resources (DOE): estimates within known productive uranium areas that are either extensions of known deposits or undiscovered deposits within known geologic trends or areas of mineralization.

Proto-control area: a specific geographic area for which geologic characteristics of the uranium concentration are known but data for reserves and production are too limited to qualify as a fully described control area.

Reasonably assured resources (RAR, NEA/IAEA, DOE): refers to uranium that occurs in known mineral deposits of such size, grade, and configuration that it could be recovered within the given production cost ranges, with currently proven mining and processing technology.

Reserves (DOE): estimated quantities of uranium in known deposits of such tonnage, grade, configuration, thickness, and depth that uranium can be recovered at, or less than, a specified cost using state-of-the-art mining and processing technologies.

Speculative potential resources (DOE): estimated quantities in undiscovered or partly defined deposits in formations or geologic settings not previously productive within a productive geologic province or subprovince or within a geologic province or subprovince not previously productive.

Resource: a concentration of naturally occurring material in such form and amount that economic extraction is currently or potentially feasible.

Speculative resources (SR, NEA/IAEA): refers to uranium, in addition to Estimated Additional Resources-Category II, that is thought to exist mostly on the basis of indirect evidence and geological extrapolations, in deposits that could be discovered with existing exploration techniques.

Speculative resources (DOI): undiscovered uranium resources that may occur either as known types of deposits in favorable areas in which no discoveries have been made or in new types of deposits not yet recognized for their economic potential.

Uncertainty: the inability to specify a single value for some variable because of limited data or information about the variable. Confidence intervals are measures of uncertainty.

Uranium deposit: a discrete uranium concentration of possible economic interest.

Uranium endowment: the uranium that is estimated to occur in rock with a grade of at least 0.01 percent $\mathrm{U}_{3} \mathrm{O}_{8}$. Unconditional endowment is based on the assumption that one or more deposits exists in the favorable area.

Uranium inventory: preproduction tons $\mathrm{U}_{3} \mathrm{O}_{8}$ at and above minimum grade of 0.01 percent $\mathrm{U}_{3} \mathrm{O}_{8}$ contained in discovered mineralized material.

Variance: a measure of variability or dispersion about the mean; the second central moment.

World-class deposit: a type of uranium deposit that is important in world uranium production. 


\title{
URANIUM RESOURCE ASSESSMENT BY THE GEOLOGICAL SURVEY: METHODOLOGY AND PLAN TO UPDATE THE NATIONAL RESOURCE BASE
}

\author{
By Warren I. Finch and Richard B. McCammon
}

ABSTRACT

Based on the Memorandum of Understanding (MOU) of September 20,1984, between the U.S. Geological Survey of the U.S. Department of Interior and the Energy Information Administration (EIA) of the U.S. Department of Energy (DOE), the U.S. Geological Survey began to make estimates of the undiscovered uranium endowment of selected areas of the United States in 1985. A modified NURE (National Uranium Resource Evaluation) method will be used in place of the standard NURE method of the DOE that was used for the national assessment reported in October 1980. The modified method, here named the "deposit-size-frequency" (DSF) method, is presented for the first time, and calculations by the two methods are compared using an illustrative example based on preliminary estimates for the first area to be evaluated under the MOU. The results demonstrate that the estimate of the endowment using the DSF method is significantly larger and more uncertain than the estimate obtained by the NURE method. We believe that the DSF method produces a more realistic estimate because the principal factor estimated in the endowment equation is disaggregated into more parts and is more closely tied to specific geologic knowledge than by the NURE method.

The DSF method consists of modifying the standard NURE estimation equation, $U=A \cdot F \cdot T \cdot G$, by replacing the factors $F \cdot T$ by a single factor that represents the tonnage for the total number of deposits in all size classes. Use of the DSF method requires that the size frequency of deposits in a known or control area has been established and that the relation of the sizefrequency distribution of deposits to probable controlling geologic factors has been determined. Using these relations, the principal scientist (PS) first estimates the number and range of size classes and then, for each size class, estimates the lower limit, most likely value, and upper limit of the numbers of deposits in the favorable area. Once these probable estimates have been refined by elicitation of the PS, they are entered into the DSF equation, and the probability distribution of estimates of undiscovered uranium endowment is calculated using a slight modification of the program by Ford and McLaren (1980).

The EIA study of the viability of the domestic uranium industry requires an annual appraisal of the U.S. uranium resource situation. During DOE's NURE Program, which was terminated in 1983, a thorough assessment of the Nation's resources was completed. A comprehensive reevaluation of uranium resource base for the entire United States is not possible for each annual appraisal. A few areas are in need of future study, however, because of new developments in either scientific knowledge, industry exploration, or both. Four geologic environments have been selected for study by the U.S. Geological Survey in the next several years: (1) surficial uranium deposits throughout the conterminous United States, (2) uranium in collapse-breccia pipes in the Grand Canyon region of Arizona, (3) uranium in Tertiary sedimentary rocks of the Northern Great Plains, and (4) uranium in metamorphic rocks of the Piedmont province in the eastern States.

In addition to participation in the National uranium resource assessment, the U.S. Geological Survey will take part in activities of the Nuclear Energy Agency of the Organization for Economic Cooperation and Development and those of the International Atomic Energy Agency.

\section{INTRODUCTION}

On September 20, 1984, the Memorandum of Understanding (MOU) between the Energy Information Administration (EIA) of the U.S. Department of Energy (DOE) and the U.S. Geological Survey (USGS) of the U.S. Department of Interior (DOI) was signed. The memo "describes the implementation of an agreement for assistance from the USGS in the assessment of U.S. potential uranium resources in support of the EIA's work under Public Law 97-415 (January 4, 1983) to develop and provide information about the viability of the domestic uranium mining and milling industry." The 1984 MOU (appendix A) is a continuant to the MOU between DOE and DOI dated November 12,1983, that called for a plan to conduct research on data collected under the National Uranium Resource Evaluation (NURE) Program and to provide for continuing the assessment of the Nation's uranium resources. The 1984 
EIA/USGS MOU returned to the USGS the full responsibility for the studies of geology and resources of uranium that were abrogated by the Atomic Energy Act of 1946. Thus, the responsibilities for uranium resource evaluation are now the same as for other minerals decreed by the USGS Organic Act of 1889.

\section{CHRONOLOGY OF ASSESSING POTENTIAL URANIUM RESOURCES}

The three basic steps that characterize the process of assessing undiscovered uranium resources are: (1) the determination (ranking) of geologic favorability within an area being studied, (2) the subjective probabilistic estimation of undiscovered endowment of uranium in the area, and (3) the economic evaluation of the undiscovered endowment. Determination of geologic favorability is based on the process of analogy in which the characteristics of the geologic setting of an area under study are compared to those of settings that contain known uranium deposits. In this process, areas are assigned a simple ranking of either favorable or unfavorable. Areas that are known insufficiently may be designated as having uncertain favorability. Subjective probabilistic estimates of the undiscovered endowment within study areas are derived primarily by comparisons to the known deposits in what are referred to as control areas. The economic evaluation of the undiscovered uranium endowment is based on several factors that include grade cutoff, thickness, depth, and mining and milling costs. Economic evaluation leads to potential uranium resource (Estimated Additional Resources) estimates of DOE. The data required to support the first two steps listed above, the methods used in estimating undiscovered endowment, and the role of the USGS in providing estimates of the undiscovered uranium endowment or resources are the main topics of this report.

\section{TERMINOLOGY OF RESOURCE REPORTING}

Terminology used to report resources probably varies more for uranium than for any other mineral commodity. Worldwide, several major classifications of economic uranium resources exist, including those of the USGS (U.S. Department of Interior, 1980), DOE (U.S. Department of Energy,
1980; Energy Information Administration, 1985), NEA/IAEA (Nuclear Energy Agency and International Atomic Energy Agency, 1984), American Society for Testing and Materials (1983), United Nations (Schanz, 1975), and Canada Department of Energy, Mines and Resources (1977). Many countries use variations of one or another of these classifications. For the purposes of this report as set out in the MOU (appendix A, section E), a modified DOE classification using in part the NEA/IAEA classification will be used (fig. 1, DOE, 1983-current). This modification correlates quite closely to the classification used by the USGS. The terms used in figure 1 are defined in the glossary. If the definitions are studied carefully, one can see that each classification is based on actual and geologic assurance of existence. Correlations in figure 1 are in many places only approximate, especially in the zone between identified resources and extensions of identified resources into undiscovered categories. Our report is basically for guiding the estimation of the undiscovered uranium resource endowment, so we concentrate on the methodology for this purpose. Guidance for making economic evaluations of the different classes of resources is beyond the scope of our report. However, those interested can learn of the cost categories used by DOE (U.S. Department of Energy, 1980; Energy Information Administration, 1985) and NEA/IAEA (Nuclear Energy Agency and International Atomic Energy Agency, 1984) by referring to their publications.

Endowment is defined as the amount of uranium in recognizable concentrations in rocks that average 0.01 percent $\mathrm{U}_{3} \mathrm{O}_{8}$ or more. Although the initial estimate of endowment is termed the conditional endowment by DOE (U.S. Department of Energy, 1980), we modify the equation to calculate unconditional endowment directly. From the unconditional endowment, one may segregate, using different grade cutoffs, the economic portion or potential uranium resources.

\section{NATIONAL URANIUM RESOURCE ASSESSMENT RESPONSIBILITIES}

According to the 1984 MOU formal agreement, the determination of geologic favorability and the estimation of undiscovered endowment are the responsibility of the USGS. The economic evaluation of the undiscovered endowment is the responsibility of the EIA. These economic resource 


\begin{tabular}{|c|c|c|c|c|c|}
\hline Agency & \multicolumn{5}{|c|}{$\begin{array}{c}\text { Resource classes } \\
\text { (see Glossary for definitions) }\end{array}$} \\
\hline $\begin{array}{l}\text { DOE (1974- } \\
1982)\end{array}$ & \multicolumn{2}{|c|}{ Reserves } & \multicolumn{2}{|c|}{ Probable Potential Resources } & $\begin{array}{c}\text { Possible and } \\
\text { Speculative } \\
\text { Potential } \\
\text { Resources }\end{array}$ \\
\hline $\begin{array}{l}\text { DOE (1983- } \\
\text { current) }\end{array}$ & \multicolumn{2}{|c|}{$\begin{array}{l}\text { Reasonably Assured Resources } \\
\text { (RAR) }\end{array}$} & \multicolumn{2}{|c|}{$\begin{array}{l}\text { Estimated Additional Resources } \\
\text { (EAR) }\end{array}$} & $\begin{array}{l}\text { Speculative } \\
\text { Resources }\end{array}$ \\
\hline \multirow{2}{*}{ DOI } & \multicolumn{3}{|c|}{ Identified } & \multicolumn{2}{|c|}{ Undiscovered } \\
\hline & $\begin{array}{l}\text { Measured } \\
\text { Reserves }\end{array}$ & $\begin{array}{l}\text { Indicated } \\
\text { Reserves }\end{array}$ & Inferred Reserves & Hypothetical & Speculative \\
\hline NEA/IAEA & \multicolumn{2}{|c|}{ Reasonably Assured Resources (RAR) } & $\begin{array}{l}\text { Estimated Additional } \\
\text { Resources I (EAR=I) }\end{array}$ & $\begin{array}{l}\text { Estimated Additional } \\
\text { Resources } \|(E A R=\|)\end{array}$ & $\begin{array}{c}\text { Speculative } \\
\text { Resources (SR) }\end{array}$ \\
\hline & \multicolumn{5}{|c|}{ Decreasing confidence in estimates } \\
\hline
\end{tabular}

FIGURE 1.-Correlation of uranium resource terminology used by DOE, 1972-1982 (U.S. Department of Energy, 1980), DOE, 1983-current (Energy Information Administration, 1985), DOI (U.S. Department of Interior, 1980), and NEA/IAEA (Nuclear Energy Agency/International Atomic Energy Agency, 1984).

estimates and the reserve and production data provided by industry are reported in the "Uranium Industry Annual" (Energy Information Administration, 1985), a new publication that replaces the former annual "Statistical Data of the Uranium Industry" report (U.S. Department of Energy, 1983). The determination of favorability and estimation of the uranium endowment for individual regions will be reported to the public in one of the regular USGS publications.

\section{PURPOSE OF THIS REPORT}

The primary purpose of this report is to describe the new method to be used by the USGS in assessing undiscovered uranium resources and to provide a step-by-step guide in its application. The method described is a modification of the standard NURE method (U.S. Department of Energy, 1980). For purposes of comparison, calculations by both methods are made in our first area of study. The new method is intended to be used by USGS scientists in their geologic studies and in assessment of potential uranium resource regions.

The second purpose of this report is to provide the public an insight into plans to continue a program to update our Nation's uranium resource base. The USGS has assumed the role of providing basic data on estimates of uranium endowment in new areas as well as reevaluations of areas assessed during the NURE program prior to 1983. These data will be applied by EIA to the economic model to develop estimates of the current economic portions for the Uranium Industry Annual Report.

\section{ACKNOWLEDGMENTS}

The DOE file material on uranium resource assessment methodology prepared by the DOE staff in the 1970s and 1980 s was particularly helpful in preparing this report. We appreciate the participation of J.K. Otton and C.T. Pierson in the elicitation of data for the example given in the first study area described below. Consultation with Luther Smith, EIA, on many aspects of the development of the DSF method and other matters related to this report are gratefully acknowledged. Helpful discussion with D.P. Harris, University of Arizona, led to the development of figure 2.

\section{METHODOLOGY}

The methods for estimating undiscovered uranium resources have received a great amount 
of attention since 1975, mainly as part of the NURE Program (Harris, 1976, 1977, 1984; U.S. Department of Energy, 1980; Harris and Agterberg, 1981; Harris and Carrigan, 1981). To a varying degree, these methods are all somewhat subjective. Recently, an effort by McCammon and others (1986) has attempted to reduce this subjectivity by integrating large data sets with genetic models in a relatively well-explored basin in New Mexico. The most widely applied method, referred to in the MOU as "the Standard Methodology," is that of the NURE Program reported by the DOE in 1980 (U.S. Department of Energy, 1980). In our current resource assessment work as prescribed in the MOU (appendix A, "Conduct of follow-on potential resource appraisal work"), we developed a modification of the NURE method to estimate the undiscovered uranium endowment. To explain this modification, the standard NURE method is first described below.

\section{STANDARD NURE METHOD}

The standard NURE method is described in the October 1980 assessment report on uranium in the United States (U.S. Department of Energy, 1980, p. 23-29), and an example of its application was given by Hetland and Grundy (1977).

The standard NURE endowment equation is as follows:

$$
{ }^{1} U=A \cdot F \cdot T \cdot G \cdot P
$$

where:

$U=$ unconditional uranium endowment in tons $\mathrm{U}_{3} \mathrm{O}_{8}$ above a cutoff grade of 0.01 percent $\mathrm{U}_{3} \mathrm{O}_{8}$,

$A=$ projected surface area of favorable ground in square miles ${ }^{2}$,

$F=$ fraction of $A$ that is underlain by endowment,

$T=$ tons of endowed rock per square mile within $A \cdot F^{2}$,

$G=$ average grade of endowment, in decimal form, and

$P=$ probability of occurrence, a factor that expresses the likelihood that one or more deposits actually exist within the favorable area.

${ }^{1}$ For simplification, we have combined equations $U=U e \cdot P_{o}$ and $U e=A \cdot F \cdot T \cdot G$, where $U e=$ conditional endowment, and use $P$ rather than $P$.

${ }^{2} A$ may be estimated also in volume (cubic miles) or length (miles); then $T$ must be expressed as either tons per cubic mile or tons per linear mile.
The formula is applied using values of $A, F, T$, $G$, and $P$ obtained from the principal scientist by a team of elicitors.

Favorable area, $A$, is obtained by measuring the area determined by scientific study to be favorable as drawn on a map, most commonly on a quadrangle map at a scale of $1: 250,000$. The area need not comprise contiguous segments, but each segment should have the potential of containing at least one deposit of the type represented in the selected control area and should be amenable to the same grade-tonnage model. Where the favorable area extends onto one or more adjacent maps, the total favorable area on all of the maps is measured and the proportion for each map is recorded. The favorable area excludes areas of mining and reserves. Because $A$ is treated as a constant, it is assigned a single value.

Factor $F$ is a variable and the lower (5 percent probability), most likely (mode), and upper (95 percent probability) values are estimated. The fraction of the favorable area, $A$, underlain by uranium endowment, $F$, can be estimated in several ways. First, $F$ can be computed directly by comparing the favorable area with a selected control area and estimating the area underlain by endowment in square miles and dividing this value then by $A$ to give $F$ as a decimal fraction. Second, the number of deposits of a selected size that are likely to exist within $A$ are estimated, based on the frequency of occurrence of deposits in the control area, and $F$ is obtained by dividing $A$ into the product of the number of deposits multiplied by the area of the average deposit. Third, if geologic information is insufficient for either of the above two ways, $F$ is estimated directly from the selected control area. In any case, the geologic reasoning in support of the estimate is recorded.

Factor $T$ is obtained by multiplying the average thickness of the endowed portion of the host rock by the mean (average) density of the rock in tons of rock per square mile per foot of thickness. $T$ is expressed as tons of rock per square mile as follows:

$$
T=c \cdot d \cdot t
$$

where:

$d=$ density of endowed rock,

$t=$ average thickness, in feet, of the layer which constitutes the endowed rock, and

$c=$ conversion factor equal to $62.4 \cdot 5,280^{2} / 2,000$

$$
=869,806.1 \frac{\text { short tons }}{\mathrm{mi}^{2} \times 1 \mathrm{ft}} \text {. }
$$


The average thickness is estimated by comparing the favorable area with the analogous control area. Lower, most likely, and upper values are estimated, and the geologic reasoning for each is recorded.

Factor $G$ is the estimated grade (percent $\mathrm{U}_{3} \mathrm{O}_{8}$ ), based either on known deposits near the favorable area or on the average grade for an analogous control area, adjusted where warranted by geologic conditions. The geologic reasoning for the choice of grade is recorded. To make $G$ consistent with units in the equation, the percentage for $G$ is converted into a decimal by dividing by 100 .

The uncertainty of the actual existence of one or more uranium deposits in the favorable area is elicited from the principal scientist. This probability factor, $P$, is expressed as a number between $0.0-1.0 . P$ is difficult to estimate, but to assume always that the favorable area is identical to the control area will result in overstating the endowment.

A computer program that treats the uncertainties associated with the factors $F, T$, and $G$ is used to calculate $U$. The result is then discussed with the principal scientist to see if the value is reasonable. If the value for $U$ is judged to be either too high or too low, the estimates for the factors in the equation are reevaluated and adjusted for justifiable geologic reasons, and a new value for $U$ is calculated. This process is repeated until the principal scientist and the elicitors are in agreement. Factor $F$ has the largest possible variation of the variables $(0 . \mathrm{X}-0.0000 \mathrm{X})$; it is the most difficult factor to estimate and is most commonly the factor adjusted most in elicitations. The difficulty in estimating $F$ led to the USGS modification given below.

In the past, DOE has applied economic factors to the unconditional endowment estimate to obtain the potential (mineable) resources in three forward-cost categories to cover a wide range of economic interests (Blanchfield, 1980; U.S. Department of Energy, 1980, p. 23-24). This procedure required a large technical staff, as well as an annually updated data base, and, with the closing of the Grand Junction Office in 1983 and continued low government budgeting, such an analysis is no longer feasible on a large scale. The responsibility of estimating potential resources is that of EIA, and now reserve data are collected annually by solicitation from industry. Because industry does not have uniform reserve calculating procedures, the reserves will be reported in more general terms. To aid in economic analysis, the USGS-generated data will include the physical and chemical characteristics of the ore (Blanchfield, 1980).

\section{DEPOSIT-SIZE-FREQUENCY METHOD, A MODIFICATION OF THE STANDARD NURE METHOD}

The need for a modified and more flexible approach to estimating the undiscovered uranium endowment within an area derives from the difficulty experienced by principal investigators during the NURE Program in estimating the factor $F$, the fraction of favorable area underlain by endowment. The difficulty in estimating $F$ arose from a number of considerations that included the kind and quality of the available data, the level of exploration activity in the favorable area, the state of knowledge about the mode of occurrence of the type of deposit being considered, and the size of the area being assessed. These difficulties were thoroughly discussed by Harris (1984, p. 364-367). In most cases, the factor $F$ was estimated by considering how many more of the best-known, usually the largest, deposits of the type being considered were likely to exist in the favorable area. Partly because of this but mostly because geologists tend to think of deposits as purely geologic entities rather than as ore bodies with specific dimensions, a modified method is developed herein whereby the number of deposits of a given size is explicitly included in the estimation equation.

To emphasize the use of geologic knowledge in the estimating process and to provide greater flexibility in the endowment equation, the standard NURE endowment equation is modified first by replacing factors $F$ and $T$ by a single factor; this factor includes estimates of the number of deposits of different deposit-size classes within the favorable area, $A$, or, equivalently, the spatial density of deposits; hence, the name "deposit-sizefrequency" method. Second, $P$ is replaced with an optional factor $L$. The general equation then becomes:

$$
\left.U=A \mid \sum_{i=1}^{k}\left(\frac{n_{i c}}{A_{c}}\right) T_{i}\right) G \cdot L
$$


where:

$U=$ unconditional uranium endowment in tons of $\mathrm{U}_{3} \mathrm{O}_{8}$ above a cutoff of 0.01 percent $\mathrm{U}_{3} \mathrm{O}_{8}$, $A=$ favorable area in square miles,

$k=$ number of deposit-size classes,

$n_{i c} / A_{c}=$ spatial density (number of deposits/unit area) of deposits of size $T_{i}$ (tons of endowed rock) in the $i$ th deposit-size class within a control area $A_{c}$,

$A_{c}=$ control area from which estimates of $n_{i c} / A_{c}$ are taken,

$G=$ average grade of endowment, in decimal fraction form, and

$L=$ optional scaling factor that expresses the relation between the endowment in the favorable area and that in either the control area or some designated subarea for which estimates of the number of deposits in different size classes have been made.

The random variables are $U,\left(n_{1 c} / A_{c}\right)+\left(n_{2 d} / A_{c}\right)+$ . . . $\left(n_{k c} / A_{c}\right), G$, and $L$. The key assumption is that these variables are independent.

The term $n_{i c} / A_{c}$ in the expression that replaces $F$ and $T$ in equation 1 is a measure of the relative number of natural discrete physical objects, whereas $F$, which is the fraction of $A$ containing the endowment, in equation 1 is an abstraction. The drawings in Figure 2 illustrate this difference. The value $F$ in the standard NURE method is dependent upon the boundary of $A$, arbitrary, and difficult to ascribe, whereas the deposit-density factor $n_{i c} / A_{c}$ is independent of the boundary of $A_{c}$. The introduction of this spatial density distribution disaggregates the input and permits one to relate size and grade of known deposits to identifiable and measurable geologic features, such as character of sedimentary or structural forms in a control area. This gives the scientist a means of evaluating the potential numbers and sizes of deposits at specific grade cutoffs in the study area. This form of representation allows adjustments either upward or downward for estimated values for the favorable area relative to the control area or proto-control area. As in the case of the standard NURE method, the size of a deposit expressed in tons of endowed rock is assumed to be statistically independent of the average grade of the endowment. The available data tend to support this assumption (Harris, 1984, p. 289).

To make the deposit-size-frequency method as flexible as possible, the principal scientist can estimate the number of deposits using one of three options, depending on the level of knowledge, extent of exploration, and size of area being assessed.

Option A: In cases where the favorable area has been examined in sufficient detail $(L=1.0)$ and where estimating directly the number and size of deposits that may occur is possible, equation 3 becomes:

$$
U=\left|\sum_{i=1}^{k} n_{i c} \cdot T_{i}\right| G
$$

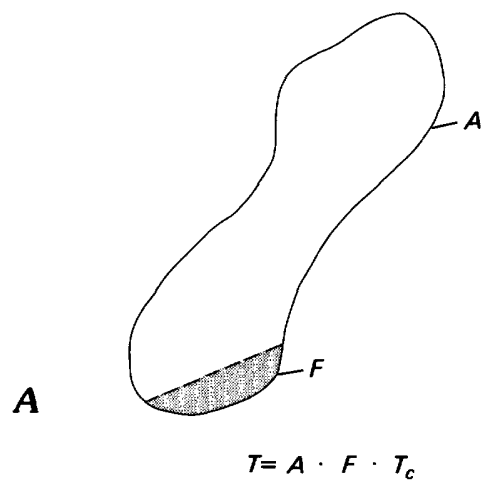

Where: $T=$ Tons of endowed rock

$F=$ Fraction of $A$ with unspecified area underlain by endowed rock

$T_{c}=$ Tons/unit area of endowed ground (equal to $T$ of equation 1)

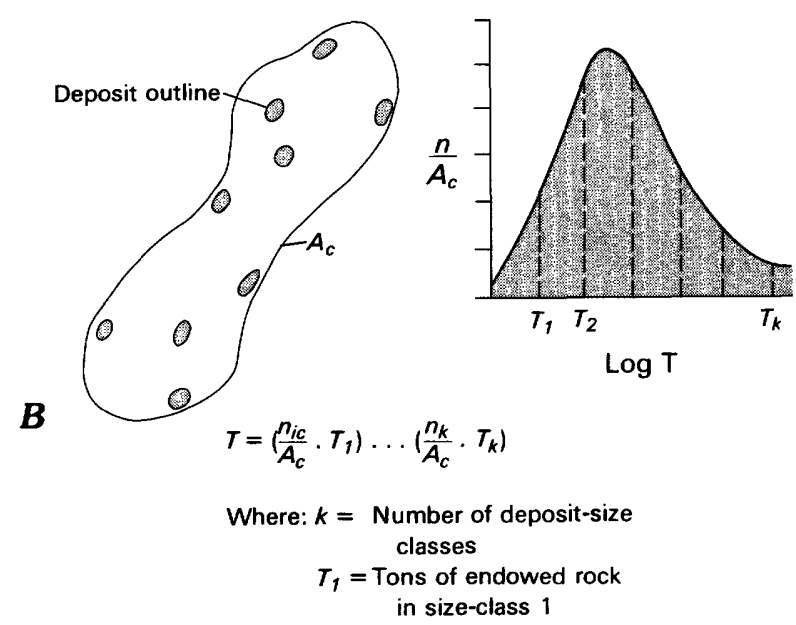

FIgURE 2.-Comparison of $F$ of the standard NURE method with the $n_{i} / A_{c}$ of the deposit-size-frequency method. $A$, standard NURE method (equation 1); $B$, deposit-sizefrequency method (equation 3 ). 
Option B: In cases where the favorable area has been examined cursorily but sufficiently so that spatial densities of deposits of different sizes can be estimated with reference to a control area $(L=1.0)$, equation 3 becomes:

$$
\left.U=A \mid \sum_{i=1}^{k}\left(\frac{n_{i c}}{A_{c}}\right) T_{i}\right) G
$$

Option C: In cases where the favorable area can be delineated but has been examined in detail only for some portion, that is, a proto-control area, $A_{c}$, so the number and size of deposits within that portion can be estimated, equation 3 becomes:

$$
U=\frac{A}{A_{c}}\left|\sum_{i=1}^{k} n_{i c} \cdot T_{i}\right| G \cdot L
$$

The factor $L$ is assumed to be independent of the other factors and is estimated by the principal scientist as the relation between the undiscovered endowment in the portion of the favorable area for which estimates of the number and size of deposits are made and the undiscovered endowment in the favorable area. $L$ can take on any positive value. Small values of $L$ are expected, generally much less than 1.0, simply because of a lack of knowledge about the favorable area. Therefore, option $C$ will result invariably in an estimate of undiscovered endowment with the widest range of possible values.

At the beginning of the elicitation, the principal scientist must decide which option $(\mathrm{A}, \mathrm{B}$, or $\mathrm{C})$ is to be used. Such a decision takes into consideration the level of knowledge about the geology, the extent of exploration, and the size of the area being assessed. Depending upon which of the three options is chosen, the appropriate values for the parameters in equations $3,4,5$, or 6 are elicited and recorded in the summary form shown in figure 3.

The relation of depth versus endowment is an important factor for economic evaluation by the EIA. Each estimate of endowment is partitioned in percentage in the required depth ranges of $0-100,101-200,201-300,301-400,401-500$, $501-1,000,1,001-1,500,1,501-2,000,2,001-3,000$, $3,001-4,000$, and 4,001-5000 $\mathrm{ft}$. The maximum depth to be considered is $5,000 \mathrm{ft}$.

\section{THE ASSESSMENT PROCEDURE}

The assessment procedure for a chosen area of study consists of a sequence of seven steps: (1) determination of geologic favorability, (2) selection of control area, (3) development (or selection of an established set) of grade-tonnage data, (4) development of deposit-size-frequency data, (5) selection of option for calculation of endowment and estimation of necessary factors through elicitation or, if the principal scientist is fully qualified, singlehandedly (review process may substitute for elicitation), (6) calculation of endowment, and (7) expert peer review of steps 1-6. Prior to beginning step 1, the principal scientist should study this manual of instructions to prepare for the elicitation and expert review.

\section{GEOLOGIC FAVORABILITY}

Determination of the geologic favorability for uranium deposits of a given area is based on analogy with the geology of an area known to contain a specific type of uranium deposit. Guides or criteria to recognize areas having similar geologic, geochemical, and geophysical characteristics have been established for the world-class and other important deposits. These criteria are reported as conclusions of hundreds of reports on areas studied during the past 30 years, and several summaries of recognition criteria are available for use in resource assessments (Mickle and Mathews, 1978; Mathews and others, 1979).

The study of an area for estimation of uranium endowment proceeds from a general determination of favorability to the specific outlining of the favorable area. Table 1 is an aid in studying and summarizing the geologic favorability of an area. From this, the actual boundaries of the favorable area are drawn on the basis of controlling geologic features, such as favorable rock outcrop; distribution of a distinctly favorable sedimentary facies; area of faulting, shearing, and fault intersections; and areal distribution of a favorable unconformity. For purposes of National resource records, the area is drawn on an appropriate National Topographic Map Service (NTMS) $2^{\circ}$ quadrangle map (scale 1:250,000).

For application of the deposit-size-frequency method, particular attention is paid to the specific geologic features that are known from an 
Grade-tonnage model:

Estimates:
A.
d:

Size class

$\begin{array}{ll}k & \begin{array}{l}\text { Lower } \\ \text { limit }^{2}\end{array} \\ 1 \\ 2 \\ 3 \\ 4 \\ 5^{4}\end{array}$

$$
A_{c}:
$$$$
t:
$$

Tons of ore ${ }^{1}$, or contained $\mathrm{U}_{3} \mathrm{O}_{8}$ per deposit
$A_{c}$

$$
\text { Depth: }
$$

Size-class density (number of deposits)

Lower

limit $^{2}$
Most

likely
$L$ :

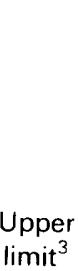

\footnotetext{
${ }^{1}$ Average grade $\left(\% \mathrm{U}_{3} \mathrm{O}_{8}\right)$ - lower: most likely: upper: Cutoff grade $\left(\% \mathrm{U}_{3} \mathrm{O}_{8}\right)$ : Indicate if ore not used.

${ }^{2}$ Lower limit taken as the 5 percent confidence level.

${ }^{3}$ Upper limit taken as the 95 percent confidence level.

${ }^{4} k$ may be less than or greater than 5 . The number and size limits of classes should reflect the size distribution of known deposits. Estimate the midpoint of the largest size class.
}

FIGURE 3.-Elicitation summary form for the deposit-size-frequency method.

analogous control area to be related to the spatial density of occurrence of uranium ore deposits. Identification of such features will aid in estimating numbers of deposits in the different size classes for the estimating equation (equations 3-6). Also, mapping the distribution of those features containing uranium deposits of a particular size will be necessary; an example is the relation of elongate tabular uranium deposits to the length and width of fluvial channels.

\section{CONTROL AREA}

A control area is a specific geographic area for which geologic characteristics (recognition criteria), uranium reserves, potential resources, and production are known. More than 50 wellestablished control areas, as well as less completely established ones, were defined during the NURE Program (Hetland and Grundy, 1977). A completely described control area of the NURE 
TABLE 1.-A form listing topics to annotate for comparison with available criteria to recognize favorability of an area for uranium (after U.S. Department of Energy, 1980, fig. 17)

\begin{tabular}{lccc}
\hline \multicolumn{1}{c}{ Topic } & Description & Fit & Rank \\
\hline Tectonic setting & - & - & - \\
Regional geology & - & - & - \\
Regional structure & - & - & - \\
Local structure & - & - & - \\
Host-rock age & - & - & - \\
Host-rock lithology(ies) & - & - & - \\
Host-rock mineralogy & - & - & - \\
Host-rock texture & - & - & - \\
Host-rock geometry & - & - & - \\
Chemistry & - & - & - \\
Alteration & - & - & - \\
Uranium minerals & - & - & - \\
Nature of mineralization & - & - & - \\
Geometry of ore body(ies) & - & - & - \\
Source of uranium & - & - & - \\
Occurrence of uranium ${ }^{1}$ & - & - & - \\
Other & - & - & - \\
\hline
\end{tabular}

${ }^{1}$ Location of mines, airborne and surface radiometric anomalies, and streamsediment and water uranium anomalies.

program consisted of the following: (1) a set of geologic recognition criteria; (2) a map of the outcrop of the host formation, the downdip extent of thoroughly explored land, and locations of mines and reserve blocks; (3) size, thickness, and grade distribution for mining properties (a mining property commonly is not a single geologic deposit as one property might cover a whole deposit, parts of several, or only a part of one deposit); (4) distribution curves for the in-place inventory of $\mathrm{U}_{3} \mathrm{O}_{8}$ by grade; (5) range in depth to ore; and (6) a set (lower limit, most likely value, and upper limit) of values for the $A, F, T$, and $G$ factors in the standard NURE equation for estimating the undiscovered uranium endowment.

In the deposit-size-frequency method, values for $F$ and $T$ are not required. In their place is a tabulation of the numbers of deposits, expressed as lower limit, most likely value, and upper limit for each size class within the control area.

Although established control areas exist for many types of uranium deposits, possibly none will be applicable to a particular area. This is the case for the study area described below where no control area exists for the newly identified type of uranium deposit in young organic-rich sediments. In this example, a proto-control area was established, based on data from the best known area but where production has not taken place. Grade-tonnage data were available for one deposit in the area.

\section{DEVELOPMENT OF GRADE-TONNAGE DISTRIBUTIONS FOR CONTROL AREAS}

Knowledge of uranium grade and tonnage distributions of deposits in a given control area is essential for the proper application of the depositsize-frequency method and of the economic model used by EIA to calculate potential Estimated Additional Resources. These grade-tonnage data will allow the principal scientist to estimate the numbers of deposits of various sizes and grades that one might expect to find in a favorable area. For the economic model, the distribution must be expressed as a set of grade-tonnage curves that show the increase in tonnage with the decrease of average grade at specified grade cutoffs.

In areas where no grade-tonnage data are available from the files of the NURE Program and where the available data are not suitable (for example, where mining property information does not correspond to a single deposit as discussed above), new grade-tonnage distributions will need to be developed. For new areas, grade-tonnage data may be developed in two ways: (1) from a single well-developed deposit in the control area or (2) from available production and reserve data on all known deposits in the well-explored part of a control area. In either case, the average grade and tons of contained $\mathrm{U}_{3} \mathrm{O}_{8}$ at selected cutoff grades are tabulated, for example:

\begin{tabular}{ccr}
\hline $\begin{array}{c}\text { Grade cutoff } \\
\left(\% \mathrm{U}_{3} \mathrm{O}_{8}\right)\end{array}$ & $\begin{array}{c}\text { Average grade } \\
\left(\% \mathrm{U}_{3} \mathrm{O}_{8}\right)\end{array}$ & Thns of $\mathrm{U}_{3} \mathrm{O}_{8}$ \\
\hline 0.01 & 0.06 & 283,000 \\
.02 & .07 & 267,000 \\
.03 & .09 & 246,000 \\
.04 & .11 & 218,000 \\
.05 & .13 & 200,000 \\
.06 & .14 & 183,000 \\
.07 & .15 & 168,000 \\
.08 & .17 & 156,000 \\
.09 & .18 & 143,000 \\
.10 & .20 & 133,000 \\
.11 & .22 & 124,000 \\
.12 & .23 & 112,000 \\
.13 & .24 & 106,000 \\
.14 & .26 & 97,000 \\
\hline
\end{tabular}

From the above data derived from Hetland and Grundy (1977), the grade-tonnage curves may be constructed as shown in figure 4. The economic model requires the slope of the average-grade line and the first three moments to calculate potential resources. 


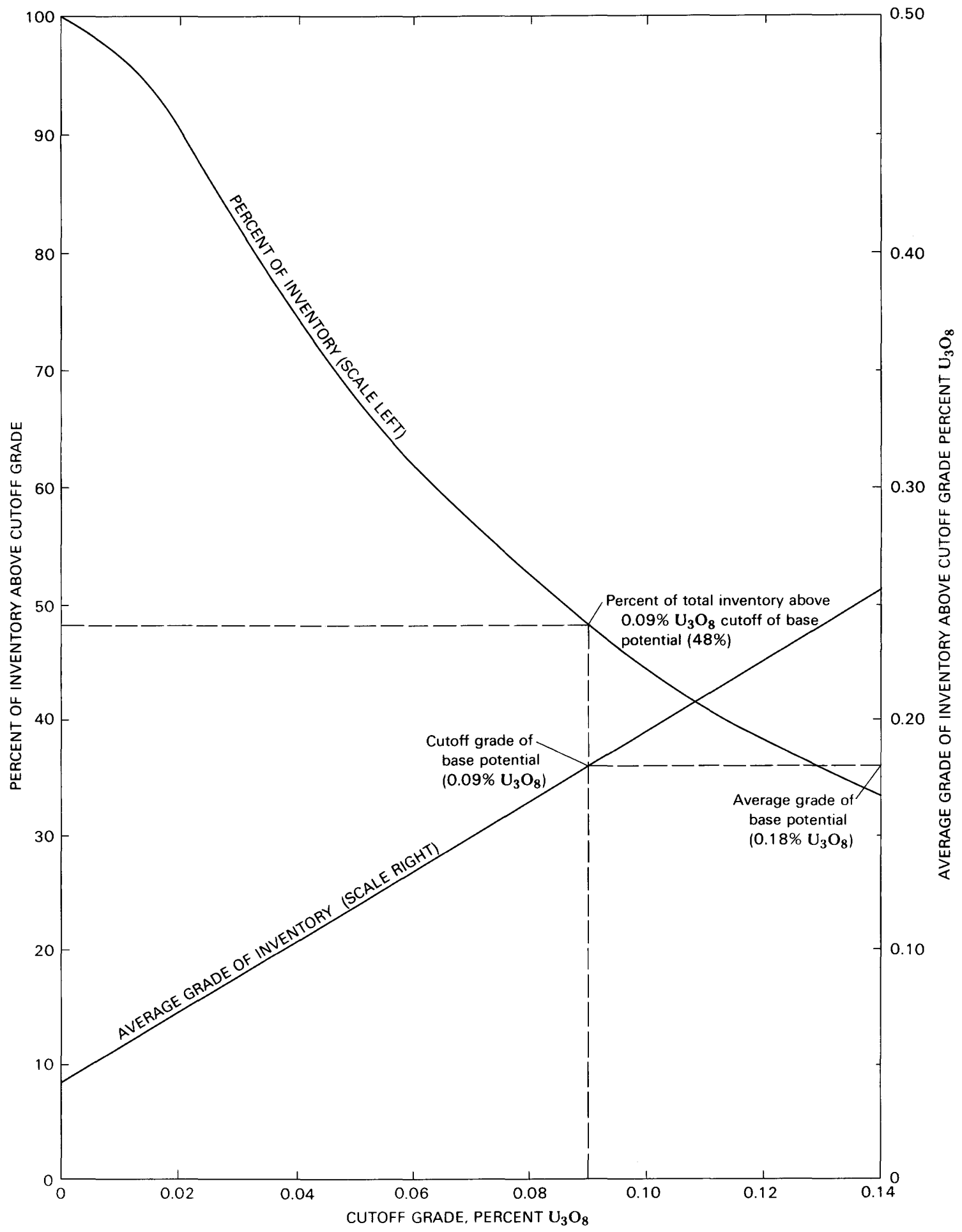

Figure 4.-Grade-tonnage curves for the Ambrosia Lake control area, New Mex. (from Hetlund and Grundy, 1977). Inventory is the total tons of pre-mining, in-place $\mathrm{U}_{3} \mathrm{O}_{8}$ at various cutoff and average grades. 


\section{DEVELOPMENT OF DEPOSIT-SIZE FREQUENCY DATA}

The initial step in the development of a sizefrequency distribution for a particular class of deposit is to compile the number of known deposits of various sizes (tons of contained $\mathrm{U}_{3} \mathrm{O}_{8}$ above a given grade cutoff) within a control or proto-control area. The sizes are ranked from smallest to largest, and the number of deposits in classes are chosen in either geometric or lognormal (not arithmetic) intervals to cover the size range of the known deposits. The number of classes should be small, generally 4-10.

\section{ELICITATION}

Elicitation of the undiscovered uranium endowment involves formalized discussion between the principal scientist and the team of experts to review the investigation and to derive the factors needed to calculate the uranium endowment of a favorable area. The elicitation is divided into three parts. The first part establishes the geologic basis for defining a favorable area, identifying the expected deposit(s) type, and selecting a control area and its corresponding grade-tonnage model. This information is recorded on the form for geologic factors shown above in table 1 , and these factors are compared directly with similar information for the control area to check the fit. The second part involves elicitation and the recording of both the values for the factors in the endowment equation and the geologic reasoning for their estimation. The third part consists of summary review of factor estimates and their geologic rationale. If necessary, the factors are modified before the calculation of the endowment. The calculation of the endowment is made using a computer program modified after the program described by Ford and McLaren (1980).

The endowment estimates are studied and discussed, and, if both groups agree that the values are reasonable, they are accepted. If not, the process is repeated until an agreement on a reasonable endowment is reached.

Elicitation is the key element in both methods. It is a convenient, relatively fast, thorough, complete, and continuous process of unbroken steps leading from the known to the undiscovered endowment. Furthermore, it leaves an audit trail that consists of favorable-area definition, selection of a control area and a grade-tonnage model, equation-factor estimates, and endowment calculation that is defensible. If necessary, any part of the process can be modified without affecting the other parts. Such feedback is the main strength of elicitation. The creditability of the estimate can be judged on the basis of the audit trail.

\section{CALCULATION OF THE ESTIMATE}

The estimate of the endowment for the depositsize-frequency method is calculated using equation $3,4,5$, or 6 , depending upon the option chosen to fit the situation applicable to the study area. The computer program described by Ford and McLaren (1980) was modified to accept input values for the number of deposits of each size class and to sum the tonnage over the range of size classes. In this summation, a perfect correlation between the number of deposits and deposit-size class is assumed.

In this report, computer generated resource numbers are not rounded to significant figures in order to permit the reader to utilize the numbers and round as desired.

\section{REVIEW PROCESS}

Review of the endowment estimate will consist of two parts: (1) scientific review by a panel of experts, one of whom will be a non-USGS person and (2) supervisory review by appropriate Branch Chiefs and by a representative of EIA. These reviews will precede publication of the estimate.

\section{COMPARISON OF THE TWO METHODS}

To compare the deposit-size-frequency method with the standard NURE method, we estimated the undiscovered endowment by both methods. The Colville-Okanogan region of Washington and Idaho was chosen for the comparison because study of the region was nearly complete by J.K. Otton, USGS, Project Chief of the Surficial Uranium Deposits Project. This region was a particularly good choice because Otton was involved in the 1980 NURE assessment. 
THE COLVILLE-OKANOGAN STUDY AREA

The Colville-Okanogan region, named after the two forests with those names, is located in the Sandpoint and Spokane NTMS $2^{\circ}$ quadrangles (fig. 5). The favorable area consists of small to large patches of outcrops of Tertiary granitic rocks and associated alluvial sediments, and thus, it is not a contiguous area of study. Nevertheless, the region may be treated as a single geologic entity with respect to its undiscovered uranium endowment. The region contains a few known young organic-rich uranium deposits, a new class of deposits thought to have a high potential for uranium production at a comparatively low cost (Otton, 1984a, 1984b). Because these deposits were recognized after 1983 , no recognition criteria or control areas were available for the assessment. Therefore, the necessary descriptions are given below.

\section{RECOGNITION CRITERIA FOR YOUNG ORGANIC-RICH URANIUM DEPOSITS}

\section{By J.K. Otton}

This new class of uranium deposits is described here as an addendum to GJBX-32 (79) prepared by Mathews and others (1979) for the NURE program. The format of this description conforms to that used by them.

Young organic-rich uranium deposit: class 260 (Otton, 1984a,b).

Tectonic setting: Mobile belt, Precambrian to middle Tertiary.

Regional geology: Faulted, sheared Precambrian to early Tertiary granitic rocks (granodiorite to granite, especially two-mica granite); silicic volcanic terranes in high plateau areas.

Climate: Cool to temperate, moderate rainfall; usually supports heavy vegetation.

Geomorphology: Glaciated terrane, generally moderate to high relief, first-through third-order streams, pothole lakes, fresh-water to alkaline marshes in closed basins.

Regional structure: Faults, fractures, and shears; a regional Tertiary unconformity may be significant.

Host rock:

Age: Late Pleistocene to Holocene.

Geometry: Long winding channel, oval basinal fillings, hill slope.

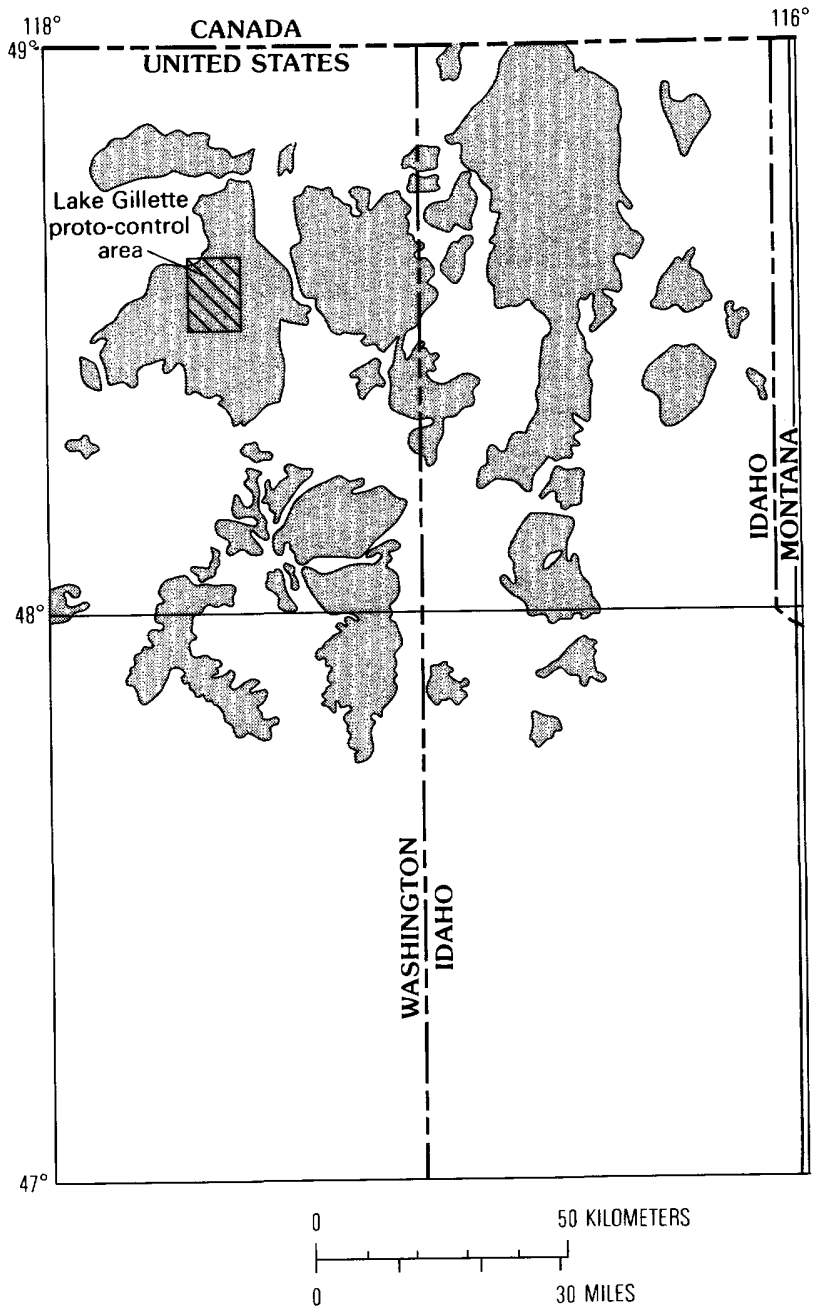

FIguRE 5.-The Colville-Okanogan favorable area (stippled) and Lake Gillette proto-control area (cross-hatched) in the Sandpoint (upper) and Spokane (lower) NTMS $2^{\circ}$ quadrangles, Washington, Idaho, and Montana. Modified by J. K. Otton after Castor and others (1982, fig. 2) and Fleshman (1982, pl. 6).

Lithology: Arkosic sand, sandy silt, silt, clay, and (or) peat; 2-100 percent organic matter.

Mineralogy: Organic matter, quartz, feldspar, mica, clay.

Texture: Medium-grained to clay-sized material, poorly to well-sorted.

Depositional environment: Fluvial, lacustrine.

Associated rocks: Granite or silicic volcanic basement in the drainage basin of the host sediment.

Alteration: Decay and humification of organic matter. 
Uranium and uranium-bearing minerals:

Primary: Uranium adsorbed by organic matter; uranium locally reduced during diagenetic processes. No crystalline mineral species recognized to date.

Secondary: Rare. Occur only where an older host is being dissected during the rejuvenation of a drainage.

Note: Because of gross secular disequilibrium, these organic-rich uranium deposits are generally very low in radioactivity. Associated elements: Minor $\mathrm{Cu}, \mathrm{Mo}, \mathrm{Pb}, \mathrm{Zn}$. Example: Flodelle Creek deposit, Stevens County, Wash.

References: Mathews and others, 1979; Otton, 1984a,b; Otton and Culbert, 1984; Cameron, 1985; Johnson and others, 1985; Macke and others, 1985; Otton and others, 1985; Otton and Zielinski, 1985, 1986; Zielinski, Bush, and Rosholt, in press; Zielinski, Otton, Wanty, and Pierson, in press.

\section{DESCRIPTION OF THE LAKE GILLETTE PROTO-CONTROL AREA FOR YOUNG ORGANIC-RICH URANIUM DEPOSITS}

\section{By J.K. Otton}

The Lake Gillette proto-control area corresponds to the boundaries of the 7.5-minute quadrangle of the same name (fig. 5). It was chosen because the best known deposit, Flodelle Creek (Joy Mining Company, 1983), occurs in the quadrangle. Two sets of data were generated: one for the standard NURE method (table 2) and the second for the deposit-size-frequency method (table 3).
TABLE 2.-Values of $A, F, t$, and $G$ for the standard NURE method.

\begin{tabular}{ll}
\hline Factor & Estimated Values \\
\hline$A$ & $49.68 \mathrm{mi}^{2}$ \\
$F^{1}$ & lower limit $=0.1 \%$ or $1 \times 10^{-3} ;$ most likely value $=0.2 \%$, \\
& or $2 \times 10^{-3} ;$ upper limit $=0.8 \%$ or $8 \times 10^{-3}$ \\
$t^{2}$ & lower limit $=1 \mathrm{ft}$, most likely $=3 \mathrm{ft}$, upper limit $=13 \mathrm{ft}$ \\
$G$ & lower limit $=0.02$, most likely $=0.03$, upper limit $=0.08$, \\
& all in percent $\mathrm{U}_{3} \mathrm{O}_{8}$
\end{tabular}

\footnotetext{
${ }^{1}$ Based on determinations of: (1) length of permanent streams plus long axis of kettle holes=24.15 mi; (2) width of outcrop of potential host sediments: range $=100-400 \mathrm{ft}$, average $=200 \mathrm{ft}$; (3) area of potentially uranium-bearing ground: $25.5 \times 10^{6} \mathrm{ft}^{2}$, or $0.914 \mathrm{mi}^{2}$; and (4) percentage of potential area mineralized: $10 \%$ (range $5-40 \%$ ).

${ }^{2} T$ was computed using equation 2.
}

\section{ESTIMATE BY THE STANDARD NURE METHOD}

The procedure began with the elicitation; the account of this exercise follows:

A summary of basic information to identify the area being investigated and the participants is as follows:

Favorable area: Colville-Okanogan.

Quadrangles: Sandpoint, WA-MT-ID (90\%); Spokane, WA-ID (10\%).

Deposit type: Young organic-rich uranium deposit.

Grade-tonnage model: Flodelle Creek.

Principal scientist: James K. Otton.

Elicitors: Warren I. Finch (leader), Richard B. McCammon, Charles T. Pierson.

TABLE 3.-Values of $A_{c}$ and size distribution of deposits for the deposit-size-frequency method

\begin{tabular}{|c|c|c|c|c|c|c|}
\hline \multirow{3}{*}{$\begin{array}{c}\text { Size } \\
\text { class } \\
(k)\end{array}$} & \multicolumn{6}{|c|}{ Proto-control area, $A_{c}=49.68 \mathrm{mi}^{2}$} \\
\hline & \multicolumn{3}{|c|}{$\begin{array}{l}\text { Size-class interval } \\
\text { (Tons mineralized rock) }\end{array}$} & \multicolumn{3}{|c|}{$\begin{array}{c}\text { Number } \\
\text { of deposits }\end{array}$} \\
\hline & $\begin{array}{l}\text { Lower } \\
\text { limit }\end{array}$ & Midpoint $^{2}$ & $\begin{array}{l}\text { Upper } \\
\text { limit }\end{array}$ & $\begin{array}{l}\text { Lower }^{1} \\
(0.05)\end{array}$ & $\begin{array}{l}\text { Most } \\
\text { likely }\end{array}$ & $\begin{array}{c}\text { Upper }^{1} \\
(0.95)\end{array}$ \\
\hline 1 & $2.5 \times 10^{3}$ & $7.9 \times 10^{3}$ & $2.5 \times 10^{4}$ & 2 & 4 & ${ }^{3} 10$ \\
\hline 2 & $2.5 \times 10^{4}$ & $7.9 \times 10^{4}$ & $2.5 \times 10^{5}$ & 4 & 8 & 18 \\
\hline 3 & $2.5 \times 10^{5}$ & $7.9 \times 10^{5}$ & $2.5 \times 10^{6}$ & 3 & 6 & 9 \\
\hline 4 & $2.5 \times 10^{6}$ & $7.9 \times 10^{6}$ & $2.5 \times 10^{7}$ & 0 & 0 & 1 \\
\hline
\end{tabular}

\footnotetext{
${ }^{1}$ Odds are 9 to 1 that the true numbers lie between lower and upper estimates.

${ }^{2}$ Midpoints of size-class intervals for size classes 1-4 are defined as the geometric mean of the upper and lower limits.

${ }^{3}$ The number of deposits in size class $k=1$ does not follow the expected distribution of most epigenetic uranium deposits for which the largest number of deposits are estimated for the smallest size class. The departure is due to the natural occurrence of the organic-rich uranium deposits. The uranium deposits are constrained in size by the volume of the alluvial valley fills. This and the fact that the valley-fill material is commonly extensive and largely continuous preclude many small uranium deposits. Furthermore, some deposits are related to spring seeps at edges of alluvial fill, and these deposits are generally of considerable size; in this area they fall mostly in size classes $K=2$ and $K=3$.
} 
Date: February 8, 1985.

Elicitation of recognition criteria for the ColvilleOkanogan favorable area (compared to recognition criteria above using form of table 1):

\begin{tabular}{l}
\hline Topic \\
\hline Tectonic setting: \\
Regional geology:
\end{tabular}

Local structure:

Host-rock age:

Host-rock geometry:

Host-rock lithology:

Host-rock mineralogy:

Host-rock texture:

Chemistry:

Alteration

Uranium minerals:

Nature of mineralization:

Geometry of ore body:

Source of uranium: Reductants/adsorbants:

Occurrence of uranium:
Granite intrusions, recent uplift (since

Cretaceous),

Pleistocene glaciation.

Faults, fractures, $\quad$ X 5 shears.

Late Pleistocene and X

Holocene.

Long sinuous channel $\mathrm{X}$ (valley-fill), oval tabular (lake, basin fill), irregular tabular (hillslope seeps).

Sand, sandy silt, silt, $\mathrm{X} \quad 3$ clay, peat, organicrich $(2-95 \%$ loss on ignition).

Organic matter, quartz, feldspar, clay, mica.

Medium to fine grained, porosity locally very high, sp $\mathrm{gr}=0.2-1.8$.

$\mathrm{U}$; trace of $\mathrm{Cu}, \mathrm{Mo}, \quad \mathrm{X}$ $\mathrm{Zn}$; no $\mathrm{CO}_{3}$, possible bacteriogenic sulfide. Diagenetic humification of organic matter, local bacteriogenic sulfide production.

No primary minerals $\mathrm{X}$ recognized.

Adsorption on organic $\mathrm{X}$ matter and clay, reduction by sulfides and organic matter.

Coextensive with host.

Granite, granodiorite. Organic, bacteriogenic sulfide.
Mobile belt.
$\mathbf{X}$

X 4

$\mathrm{X}$

$\mathbf{X}$

X 1

$\mathrm{X} 2$

$\mathrm{X}$

\begin{tabular}{cccc}
\hline Factor & $\begin{array}{c}\text { Lower } \\
(0.05)\end{array}$ & $\begin{array}{c}\text { Most } \\
\text { likely }\end{array}$ & $\begin{array}{c}\text { Upper } \\
(0.95)\end{array}$ \\
\hline$A$ & - & 2020 & - \\
$F$ & 0.001 & 0.002 & 0.008 \\
$d$ & .7 & 1.2 & 1.5 \\
$t$ & 1 & 3 & 8 \\
$G$ & .02 & .03 & .08 \\
$P$ & - & 1.0 & - \\
\hline
\end{tabular}

${ }^{1}$ Odds are 9 to 1 that the values lie between the lower and upper estimates.

The value of $T$, tons of rock per square mile with $A \cdot F$, is calculated using equation 2 .

Rationale for estimation of endowment-equation factors

The favorable area is geologically very similar to the Lake Gillette proto-control area (see above). Furthermore, reconnaissance of the two $2^{\circ}$ quadrangles has revealed anomalous uranium concentrations in young organic-rich sediments throughout most of the favorable area:

$A$ Measured directly from geologic maps, includes all granite outcrop areas (fig. 5).

$F$ Based on two values: (1) percentage of $A$ underlain by wetland (environment generally most favorable for uranium deposits), and (2) estimate of the part of the wetland that may contain uranium ( $>100 \mathrm{ppm} \mathrm{U}_{3} \mathrm{O}_{8}$ ). The wetland area is measurable from topographic sheets (length of permanent stream and long axis of lakes times the average width). Fraction of uraniferous area is subjectively estimated at 10 percent.

$G$ Based on Flodelle Creek deposit at cutoff of $100 \mathrm{ppm} \mathrm{U}_{3} \mathrm{O}_{8}$.

$P$ Considered to be 1.0 because of adjacent control area and of established presence of similar deposits.

Using the computer program described by Ford and McLaren (1980), the endowment was calculated using equation 1 . The mean value of the unconditional uranium endowment within the favorable area is 8,018 tons of contained $\mathrm{U}_{3} \mathrm{O}_{8}$. The probability distribution for the endowment is:

Percentiles for endowment

\begin{tabular}{cc|cc}
\hline $\begin{array}{c}\mathrm{U}_{3} \mathrm{O}_{8} \\
\text { (tons) }\end{array}$ & $\begin{array}{c}\text { Probability } \\
\text { unconditional } \\
\text { (in percent) }\end{array}$ & $\begin{array}{c}\mathrm{U}_{3} \mathrm{O}_{8} \\
\text { (tons) }\end{array}$ & $\begin{array}{c}\text { Probability } \\
\text { unconditional } \\
\text { (in percent) }\end{array}$ \\
\hline 1,977 & 0.05 & 5,745 & 0.55 \\
2,142 & .10 & 6,547 & .60 \\
2,307 & .15 & 7,493 & .65 \\
2,507 & .20 & 8,632 & .70 \\
2,805 & .25 & 10,049 & .75 \\
3,121 & .30 & 11,855 & .80 \\
3,514 & .35 & 14,301 & .85 \\
3,960 & .40 & 17,955 & .90 \\
4,468 & .45 & 24,721 & .95 \\
5,058 & .50 & & \\
\hline
\end{tabular}


Thus, the odds are 9 to 1 that the true endowment in the favorable area is between 1,977 and 24,721 tons of contained $\mathrm{U}_{3} \mathrm{O}_{8}$.

\section{ESTIMATE BY THE DEPOSIT-SIZE-FREQUENCY METHOD}

The summary of basic information to identify the area being investigated is the same as given above. C. T. Pierson did not take part in the elicitation, which took place later.

Principal scientist: James K. Otton.

Elicitors: Richard B. McCammon (leader), Warren I. Finch.

Date: July 18, 1985.

The elicitation of recognition criteria is identical to those given above for the standard NURE. Estimates made of the most likely number of deposits and lower and upper bounds of number of deposits within each of four size classes are summarized in table 4. The values for $A$ and $G$ are the same as for the standard NURE method.

The endowment for the Lake Gillette protocontrol area is calculated using equation 6 . The program to combine the input values and to generate the distribution of the unconditional endowment, $U$, is identical to that of Ford and McLaren (1980), except that the estimates of the numbers of deposits in the different size classes are assumed to be perfectly correlated. Based on the estimated number of deposits in each of the four deposit-size classes, the unconditional mean value of the uranium endowment within the Lake Gillette proto-control area is calculated as 3,222 tons of contained $\mathrm{U}_{3} \mathrm{O}_{8}$. The probability distribution for the uranium endowment of the Lake Gillette proto-control area is:

Percentiles for endowment

\begin{tabular}{rc|cc}
\hline $\begin{array}{c}\mathrm{U}_{3} \mathrm{O}_{8} \\
\text { (Tons) }\end{array}$ & $\begin{array}{c}\text { Probability } \\
\text { unconditional } \\
\text { (in percent) }\end{array}$ & $\begin{array}{c}\mathrm{U}_{3} \mathrm{O}_{8} \\
\text { (Tons) }\end{array}$ & $\begin{array}{c}\text { Probability } \\
\text { unconditional } \\
\text { (in percent) }\end{array}$ \\
\hline 560 & 0.05 & 2,838 & 0.55 \\
795 & .10 & 3,139 & .60 \\
1,009 & .15 & 3,475 & .65 \\
1,215 & .20 & 3,857 & .70 \\
1,421 & .25 & 4,301 & .75 \\
1,630 & .30 & 4,843 & .80 \\
1,846 & .35 & 5,532 & .85 \\
2,072 & .40 & 6,494 & .90 \\
2,306 & .45 & 8,144 & .95 \\
2,562 & .50 & & \\
\hline
\end{tabular}

Thus, the odds are 9 to 1 that the true endowment is between 560 and 8,144 tons of contained $\mathrm{U}_{3} \mathrm{O}_{8}$ in the proto-control area, $A_{c}$.

To expand this estimate to include the undiscovered uranium endowment in $A$, the favorable area, the similarity of the favorable area to the protocontrol area must be judged to complete the estimate, and the principal scientist must estimate factor $L$.

For this example, the lower limit, the most likely value, and the upper limit of $L$ were estimated subjectively as $0.05,0.1$, and 1.0 , respectively. Thus, the odds are 9:1 that the favorable area is at least $1 / 20$ th as endowed or at most equally endowed as the control area; most likely, it is $1 / 10$ th as endowed.

Based on this determination of the probability factor, the unconditional mean value of the uranium endowment within the favorable area was calculated as 35,299 tons of contained $\mathrm{U}_{3} \mathrm{O}_{8}$. The probability distribution for the endowment of the Coleville-Okanogan favorable area is:

Percentiles for endowment

\begin{tabular}{rc|cc}
\hline $\begin{array}{c}\mathrm{U}_{3} \mathrm{O}_{8} \\
\text { (Tons) }\end{array}$ & $\begin{array}{c}\text { Probability } \\
\text { unconditional } \\
\text { (in percent) }\end{array}$ & $\begin{array}{c}\mathrm{U}_{3} \mathrm{O}_{8} \\
\text { (Tons) }\end{array}$ & $\begin{array}{c}\text { Probability } \\
\text { unconditional } \\
\text { (in percent) }\end{array}$ \\
\hline 6,738 & 0.05 & 23,631 & 0.55 \\
7,428 & .10 & 27,581 & .60 \\
8,118 & .15 & 32,407 & .65 \\
8,808 & .20 & 38,240 & .70 \\
9,885 & .25 & 45,517 & .75 \\
11,338 & .30 & 54,913 & .80 \\
13,000 & .35 & 67,707 & .85 \\
15,009 & .40 & 86,883 & .90 \\
17,448 & .45 & 122,320 & .95 \\
20,285 & .50 & & \\
\hline
\end{tabular}

Thus, the odds are 9 to 1 that at least 6,738 tons or at most 122,320 tons of contained $\mathrm{U}_{3} \mathrm{O}_{8}$ exist in the favorable area.

The rationales for the remaining parameters are as follows:

1. Number of size-class intervals: a geometric scale was used in defining deposit size. The lower limit of the smallest size class was chosen to include the smallest known deposit, and the largest size class interval was chosen to allow for deposits larger than the largest known deposit.

2. Numbers of deposits in the different size classes: the total favorable area is divided into isolated parts and reconnaissance 
mapping and sampling permitted the assignment of varying degrees of favorability. Furthermore, lengths and widths of streams varied so that the permissible maximum size of deposit was apparent. Comparison of these observations with the character of the Gillette Creek control area permitted deposits larger than the largest known deposit in the control area.

3. Estimated value of $L$ : parts of $A$ are less favorable than the proto-control area, and other parts are more favorable. The lower limit, most likely value, and upper limit values of $L$ were estimated on the basis of reconnaissance sampling and mapping.

\section{DISCuSSION}

In the Colville-Okanogan favorable area, the estimate of the unconditional mean value of uranium endowment obtained using the depositsize-frequency method is 35,299 tons of contained $\mathrm{U}_{3} \mathrm{O}_{8}$, which is 4.4 times the mean value of 8,018 tons obtained using the standard NURE method. Moreover, the ratio of the range defined here as the difference between the 5th and the 95th percentiles of the probability distribution of the uranium endowment obtained by the deposit-sizefrequency method to the range defined similarly for the standard NURE method is 5.1. The estimate of uranium endowment obtained by the deposit-size-frequency method, therefore, is larger and has a greater range of values as compared to the standard NURE method. Similar results were reported by Harris and Carrigan (1981) and McCammon and others (1986) for estimates of uranium endowment that were compared to those obtained using the standard NURE method in the San Juan Basin, New Mex. In general, the more disaggregation of the input values in the estimating equation and the more the parameters in the equation are based on geologic criteria, the greater the expected value and the greater the uncertainty. As Harris (1984) suggested, the greater the degree to which the mental processes receive support and aid in the estimation task, the less narrow and less conservative the estimate. We believe that the DSF method permits the utilization of the Principal Scientist's geological knowledge in a less subjective manner than was possible in the standard NURE method, and that this represents at least a qualitative improvement in the appraisal of undiscovered uranium resources.

\section{REPORTING OF ENDOWMENT AND INTEGRATION INTO THE NATIONAL RESOURCE BASE}

The estimates of the undiscovered uranium endowment made by the USGS will be transmitted to the EIA through an interagency memorandum report. The report will primarily consist of data with very brief descriptions of geology, uranium deposits, and rationales for estimating the factors in the endowment equation. In addition, for entry into the established National NURE data file, the necessary identification, estimation of endowment factors, and supporting information will be reported on the standard NURE form given in figure 6.

To be consistent with the existing NURE database and to allow follow-up work to update National estimates of potential resources, the endowment factors $A, F, T, G$, and $P$ in the standard NURE method will be reported in terms of the deposit-size-frequency method as follows:

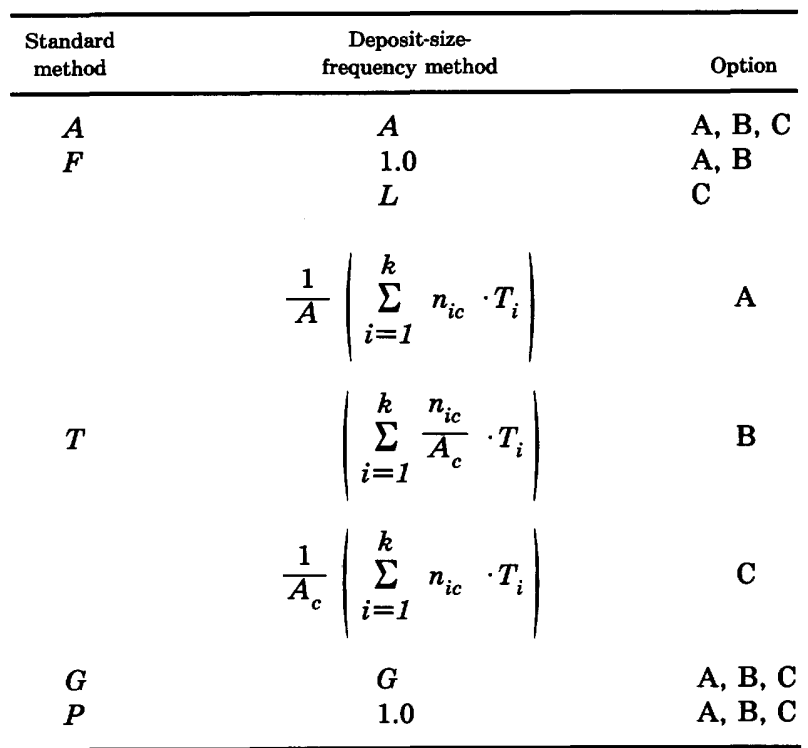

For either method, the first four central moments of $U$, the unconditional undiscovered endowment, are handled identically with respect to the subsequent application of the economic model. 
I. IDENTIFICATION

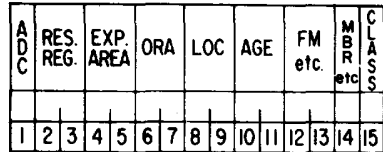

Resource Region

Exploration Areo

Formation

Ore Reserve Areo

Member

Locolity

Deposit Type

II. ESTIMATION OF ENDOWMENT

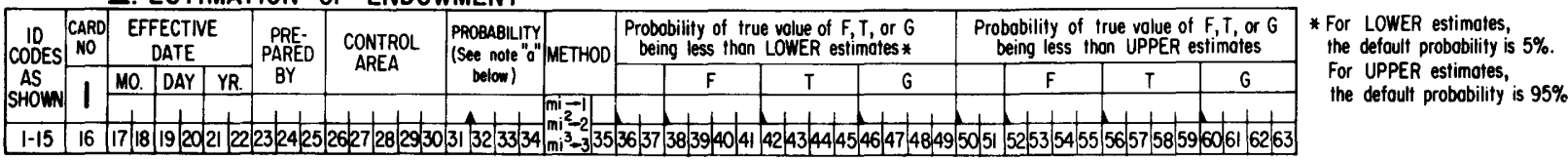

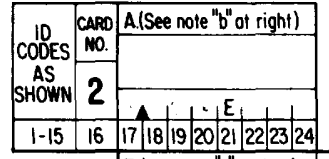

a. Probability of of least one deposit containing ot leost 10 tons of $\mathrm{U}_{3} \mathrm{O}_{8}$ of a minimum grode of $0.01 \% \mathrm{U}_{3} \mathrm{O}_{8}$ b. $A=$ oreo of fovoroble ground

in square, lineor, or cubic miles.

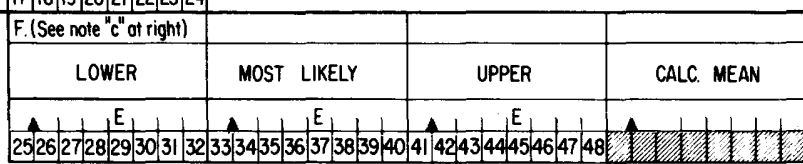

c. $F=$ froction of " $A$ " postulated to be underlain by

(or associated with) uranium endowment.

ID CARD T. (See note "d" of right)

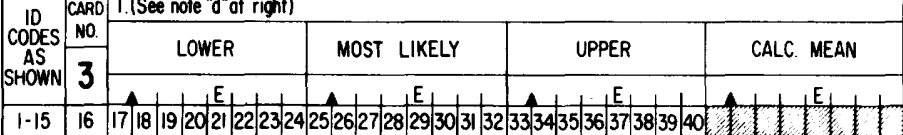

\begin{tabular}{|c|c|c|c|c|c|c|c|c|}
\hline \multicolumn{8}{|c|}{ G.(See note "e" ot right) } & \multirow{2}{*}{$\begin{array}{l}\text { MEAN URANIUM } \\
\text { ENDOWMENT } \\
\text { IN TONS } \mathrm{U}_{3} \mathrm{O}_{8}\end{array}$} \\
\hline LOWER & $\% U_{3} \mathrm{O}_{8}$ & $\begin{array}{l}\text { MOST } \\
\text { LIKELY }\end{array}$ & $\%_{0} U_{3} O_{B}$ & UPPER & $\% \mathrm{U}_{3} \mathrm{O}_{8}$ & $\begin{array}{l}\text { CALC. } \\
\text { MEAN }\end{array}$ & $\% U_{3} 0_{8}$ & \\
\hline \begin{tabular}{|l|l|l|l|}
41 & 42 & 43 & 4 \\
\end{tabular} & & $15|46 / 47|$ & & & & & & \\
\hline
\end{tabular}

III. BACKUP INFORMATION AND ALLOCATION OF POTENTIAL

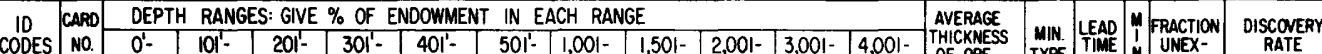

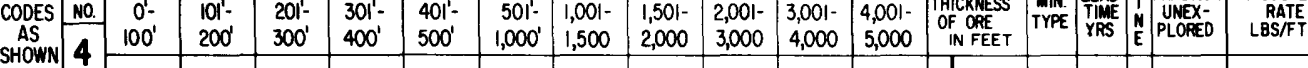

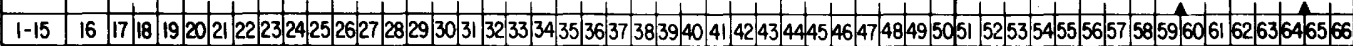

\begin{tabular}{|c|c|c|c|c|c|c|c|c|c|c|c|c|c|c|c|c|c|c|c|}
\hline \multirow{3}{*}{$\begin{array}{c}10 \\
\text { CODES } \\
\text { AS } \\
\text { SHOWN }\end{array}$} & \multirow{3}{*}{\begin{tabular}{|c|} 
CARD \\
NO.
\end{tabular}} & \multicolumn{8}{|c|}{ GEOLOGIC TYPES } & \multicolumn{10}{|c|}{ STATES } \\
\hline & & TYPE & $\%$ & TYPE & $\%$ & TYPE & $\%$ & TYPE & $\%$ & ST & $\%$ & ST & $\%$ & ST & $\%$ & ST & $\%$ & ST & $\%$ \\
\hline & & & & & & & & & & & & & & & & & & & \\
\hline $1-15$ & 16 & \begin{tabular}{|l|l|}
17 & 18 \\
\end{tabular} & \begin{tabular}{l|l}
19 & 2 \\
\end{tabular} & 2223 & 170 & \begin{tabular}{|l|l|}
26 & 27 \\
\end{tabular} & & $30 \mid 31$ & 32 & 435 & & 394 & 414 & $43 \sqrt{4}$ & 154 & 77 & & 51 & 3 \\
\hline
\end{tabular}

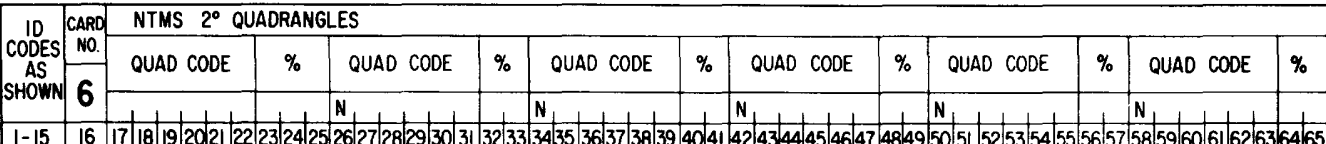

\begin{tabular}{|c|c|c|c|c|c|c|c|c|c|c|c|c|c|c|c|c|c|c|c|c|c|c|c|c|c|}
\hline \multirow{3}{*}{\multicolumn{2}{|c|}{\begin{tabular}{|c|c} 
ID & CA \\
CODES & $\mathrm{N}$ \\
AS & \\
SHONN & \\
\end{tabular}}} & \multicolumn{24}{|c|}{ LAND STATUS } \\
\hline & & TYPE & $\%$ & TYPE & $\%$ & TYPE & $\%$ & TYPE & $\%$ & TYPE & $\%$ & TYPE & $\%$ & TYPE & $\%$ & TYPE & $\%$ & TYPE & $\%$ & TYPE & $\%$ & TYPE & $\%$ & TYPE & $\%$ \\
\hline & & & & & & & & & & & & & & 1 & & & & & & & & & & & \\
\hline
\end{tabular}

Figure 6.-Uranium endowment data form. 


\section{STRATEGY TO UPDATE THE NATIONAL URANIUM ENDOWMENT ESTIMATES}

Private exploration for uranium in the United States has declined in recent years. The exploration work that has been done, however, has generated important new geologic data that can be utilized in the reevaluation of estimations of undiscovered uranium resources made by the DOE previously and in the estimations of resources for new areas discovered since 1983.

Data on the projected domestic uranium resource capability under various market assumptions are required by the Energy Information Administration for its annual assessment of the viability of the domestic uranium mining and milling industry. Within this context, an annual reappraisal is required of the Nation's undiscovered (potential) uranium resource base to incorporate, to the extent practicable, new geological data developed during private exploration activities and to assess the results of exploration activities on undiscovered resources.

The strategy of the USGS is to select for study either currently assessed or new unassessed areas where recent exploration developments or new geologic and related information have become available. In 1984, four geologic environments were identified for USGS uranium resource assessments. They are: (1) surficial uranium deposits (SUDS) throughout the conterminous United States, (2) uranium in collapse-breccia pipes in the Grand Canyon region of northwestern Arizona, (3) uranium in Tertiary sedimentary rocks of the Northern Great Plains, and (4) uranium in metamorphic rocks of the Piedmont physiographic province in the eastern United States. The SUDS areas are in a recently recognized environment of uranium accumulation in young sediments and the six general areas selected are: (1) Mesozoic-Tertiary granite terranes of Washington and Idaho, (2) Jurassic and Cretaceous Sierra Nevada terranes of California and Nevada, (3) the Cretaceous-Tertiary Idaho batholith region, (4) the Precambrian gneiss-granite terrane of the Front Range in Colorado, (5) the Paleozoic granite terrane in the New England States, and (6) the Precambrian gneiss-granite terrane of the Piedmont Province of the eastern States (fig. 7).

To support and prepare for the assessment of the four selected geologic environments, the USGS is carrying out projects to improve the understanding of the geologic habitats of uranium ores in these as well as other environments and to develop guides and criteria to delineate areas favorable for undiscovered uranium deposits (Fouch and Ridgely, 1985). In these four research projects, 64 NTMS $2^{\circ}$ quadrangle maps have been selected for uranium endowment estimation. They have been divided into $28 \mathrm{~A}$ priority (most likely to contain more than 500 tons $\mathrm{U}_{3} \mathrm{O}_{8}$ to be added to the resource base) and $36 \mathrm{~B}$ priority (less likely to add 500 tons to the resource base) quadrangles as shown in figure 8 and table 4. More than one environment will be studied in some quadrangles. The quadrangle total for each of the four geologic environments expressed as a fraction of A priority/B priority breaks down as: (1) SUDS, 14/30; (2) pipes, 4/0; (3) Northern Great Plains, 1/0; and (4) metamorphic-rock hosted, Piedmont, 9/9.

The schedule for completion of assessment of the four environments is uncertain because of restraints on budget and personnel and because of the unknown amount of time to complete field and laboratory studies in each quadrangle. The first two quadrangles in the SUDS project to be completed are the Sandpoint and Spokane in Washington, Montana, and Idaho. The example in this report is based on preliminary trials on the elicitation and calculations of the favorable area in these quadrangles.

\section{INTERNATIONAL NUCLEAR ENERGY MINERALS INFORMATION}

Current information on raw materials of the nuclear energy fuels, uranium and thorium, is a vital input for analyses made by two international organizations, the Organization for Economic Cooperation and Development, OECD (NEA), and the International Atomic Energy Agency, IAEA. The USGS has taken part in numerous program activities of these organizations beginning with the first United Nations International Conference on Peaceful Uses of Atomic Energy in 1955.

In the past 10 years, the USGS has made many contributions to the work of the IAEA. In particular, it has contributed information concerning thorium geology and resources and uranium program activities related to uranium exploration to the U.S. Department of Energy for inclusion in the OECD-IAEA (NEA and IAEA, 1984) joint report (commonly called the "Red Book") titled "Uranium: Resources, Production and Demand," published every two years. The role of the USGS 


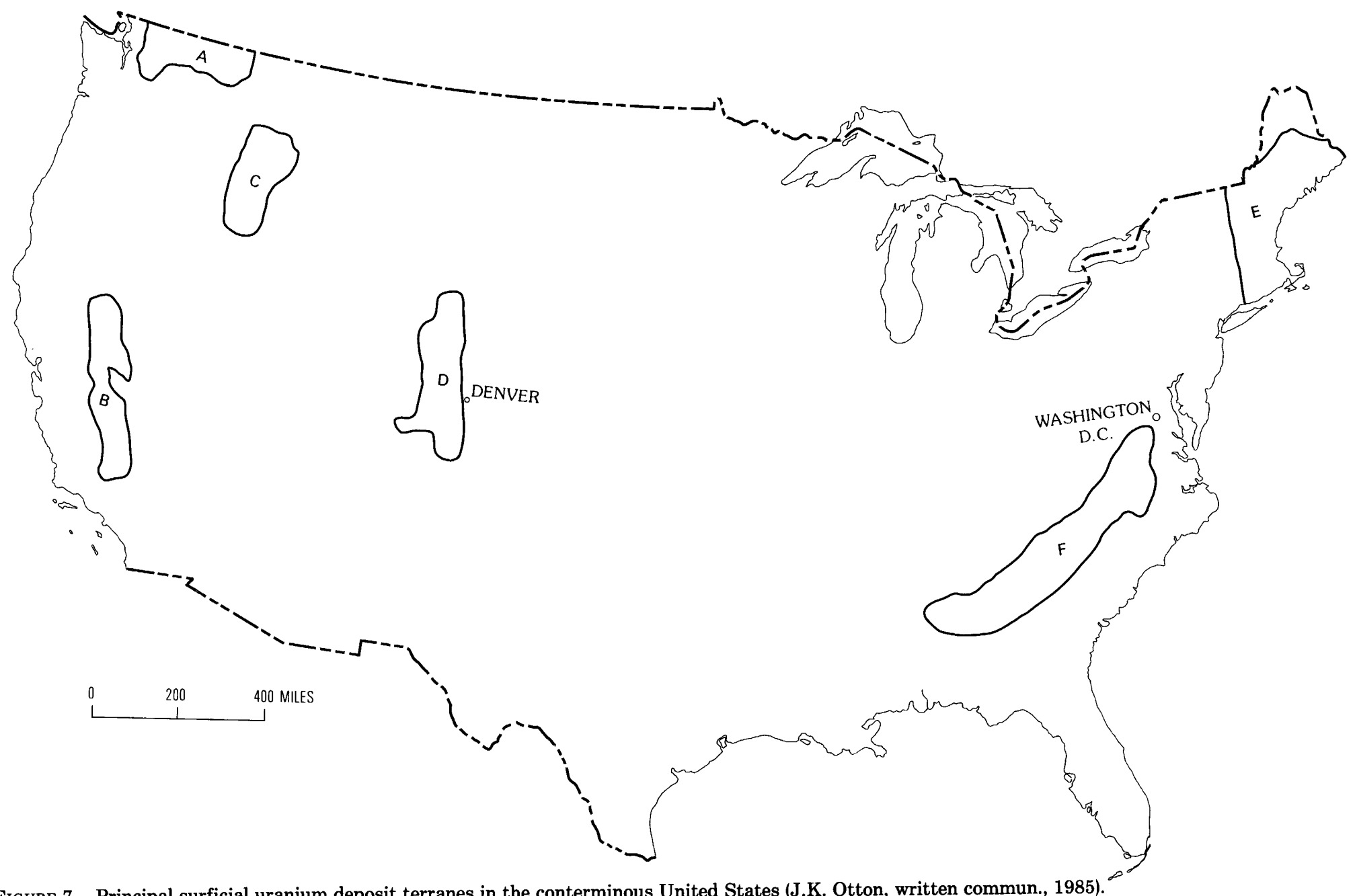

FIGURE 7.-Principal surficial uranium deposit terranes in the conterminous United States (J.K. Otton, written commun., 1985).
A. Washington-Idaho, Mesozoic-Tertiary granites
B. California-Nevada, Jurassic and Cretaceous Sierra Nevada granites
C. Idaho, Cretaceous-Tertiary granites
D. Colorado Front Range, Precambrian gneiss-granites
E. New England, Paleozoic granites
F. Piedmont physiographic province, Precambrian gneiss-granites. 


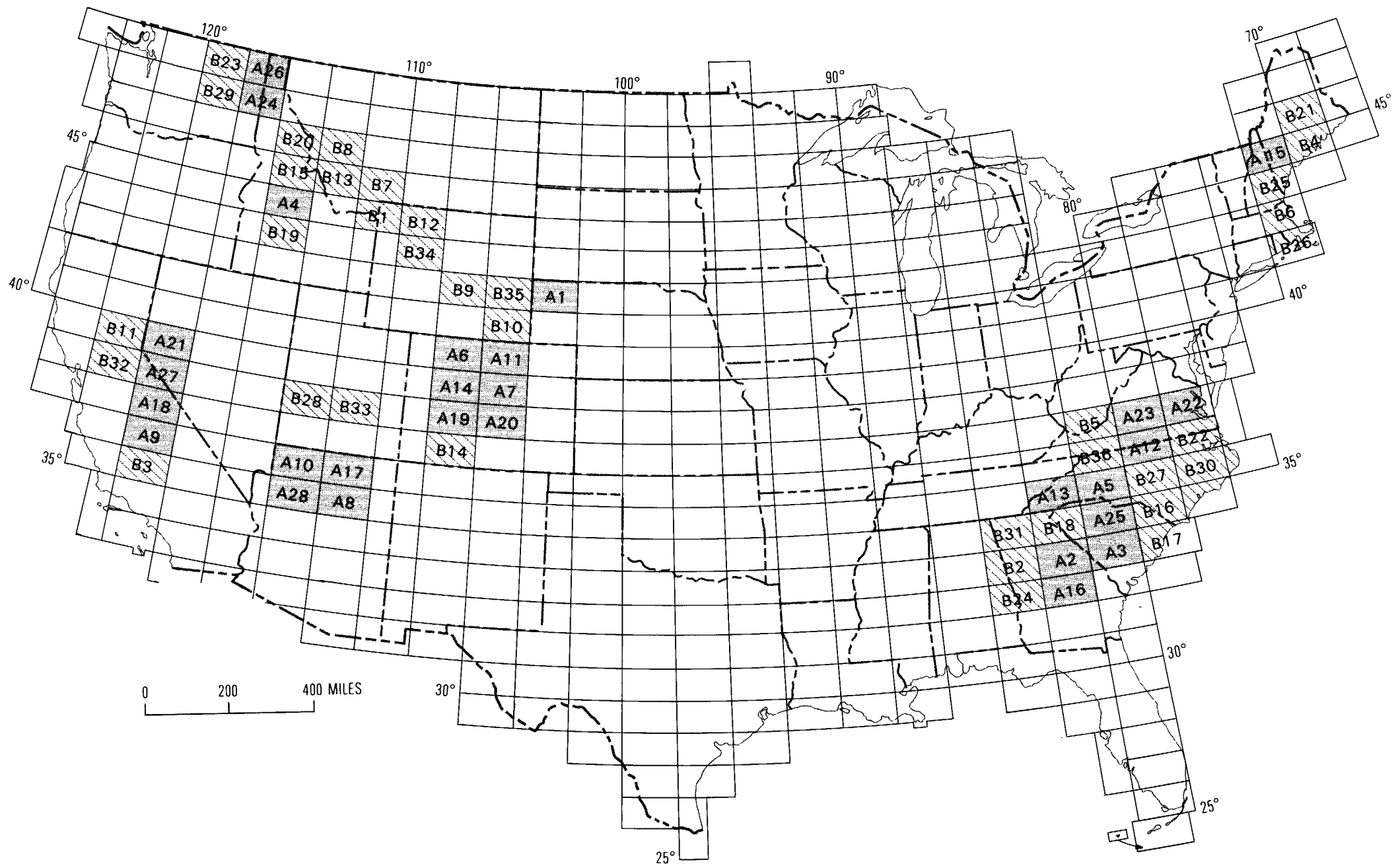

FIGURE 8.-Map of the conterminous United States showing A-priority (shaded) and B-priority (cross-hatched) NTMS $2^{\circ}$ quadrangles for uranium endowment estimation. See table 4 for identification of quadrangles. 
TABLE 4.-Index list to NTMS $2^{\circ}$ quadrangles in conterminous United States selected to be assessed for their uranium resources by the U.S. Geological Survey

[Keyed to figure 8]

\begin{tabular}{lll}
\hline & \multicolumn{1}{c}{ A PRIORITY } \\
\hline $\begin{array}{cll}\text { Map } \\
\text { no. }\end{array}$ & \multicolumn{1}{c}{ Name, } \\
State & \multicolumn{1}{c}{$\begin{array}{c}\text { Type of } \\
\text { deposit }\end{array}$} \\
\hline A1 & Alliance, NB & Sandstone-type \\
A2 & Athens, GA, SC & Vein \\
A3 & Augusta, SC & Vein \\
A4 & Challis, ID & SUDS \\
A5 & Charlotte, NC & Vein \\
A6 & Craig, CO & SUDS \\
A7 & Denver, CO & SUDS \\
A8 & Flagstaff, AZ & Collapse-breccia pipe \\
A9 & Fresno, CA & SUDS \\
A10 & Grand Canyon, AZ & Collapse-breccia pipe \\
A11 & Greeley, CO & SUDS \\
A12 & Greensboro, VA & Vein \\
A13 & Knoxville, TN, NC & Vein \\
A14 & Leadville, CO & SUDS \\
A15 & Lewiston, ME, NH & SUDS \\
A16 & Macon, GA & Vein \\
A17 & Marble Canyon, AZ & Collapse-breccia pipe \\
A18 & Mariposa, CA, NV & SUDS \\
A19 & Montrose, CO & SUDS \\
A20 & Pueblo, CO & SUDS \\
A21 & Reno, NV & SUDS \\
A22 & Richmond, VA & Vein \\
A23 & Roanoke, VA & Vein \\
A24 & Sandpoint, WA, ID & SUDS \\
A25 & Spartanburg, SC, NC & Vein \\
A26 & Spokane, WA, ID & SUDS \\
A27 & Walker Lake, CA, NV & SUDS \\
A28 & Williams, AZ & Collapse-breccia pipe \\
\hline & & \\
& &
\end{tabular}

B PRIORITY

\begin{tabular}{lll}
\hline B1 & Ashton, WY & SUDS \\
B2 & Atlanta, GA & SUDS \\
B3 & Bakersfield, CA & SUDS \\
B4 & Bangor, ME & SUDS \\
B5 & Bluefield, WV, VA & Vein \\
B6 & Boston, MA & SUDS \\
B7 & Bozeman, MT & SUDS \\
B8 & Butte, MT & SUDS \\
B9 & Casper, WY & SUDS \\
B10 & Cheyenne, WY & SUDS \\
B11 & Chico, CA & SUDS \\
B12 & Cody, WY & SUDS \\
B13 & Dillon, MT & SUDS \\
B14 & Durango, CO & SUDS \\
B15 & Elk City, ID, MT & SUDS \\
B16 & Florence, SC, NC & Vein \\
B17 & Georgetown, SC & Vein \\
B18 & Greenville, GA, SC & Vein \\
B19 & Hailey, ID & SUDS \\
B20 & Hamilton, ID, MT & SUDS \\
B21 & Millinocket, ME & SUDS \\
B22 & Norfolk, VA, NC & Vein \\
B23 & Okanogan, WA & SUDS \\
& &
\end{tabular}

B32

B33

B34

B35

B36

$\begin{array}{ll}\text { Phenix City, LA, GA } & \text { SUDS } \\ \text { Portland, NH, ME } & \text { SUDS } \\ \text { Providence, RI, MA, CT } & \text { SUDS } \\ \text { Raleigh, NC } & \text { Vein } \\ \text { Richfield, UT } & \text { SUDS } \\ \text { Ritzville, WA } & \text { SUDS } \\ \text { Rocky Mount, NC } & \text { Vein } \\ \text { Rome, GA } & \text { SUDS } \\ \text { Sacramento, CA } & \text { SUDS } \\ \text { Salina, UT } & \text { SUDS } \\ \text { Thermopolis, WY } & \text { SUDS } \\ \text { Torrington, WY } & \text { SUDS } \\ \text { Winston Salem, NC, VA } & \text { Vein }\end{array}$

has increased since the signing of the 1984 MOU, particularly as being formally represented on the NEA/IAEA Working Party on Uranium Resources. Furthermore, the closing of DOE's Grand Junction Operations Office in 1983 has increased our involvement in the field of uranium geology to the IAEA.

As a member state of the IAEA, the United States reports its uranium resources, production, and other pertinent resource information to the Working Party on Uranium Resource, Production and Demand on a regular basis, normally every two years. The responsibility of reporting of U.S. numerical resource data for inclusion in the biennial "Red Book" as a joint report by OECD's NEA and the IAEA (NEA and IAEA, 1984) is the prime responsibility of the EIA, whereas the reporting of supporting geologic data on both uranium and thorium is the prime responsibility of the USGS (appendix A, section G).

\section{REFERENCES CITED}

American Society for Testing and Materials, 1983, Standard classification system for uranium resources, in 1982, Annual Book for ASTM Standards: Philadelphia, Penn. 19103, Designation E 901-82, 15 p.

Blanchfield, D.M., 1980, Methodology for uranium resource estimates and reliability, in Uranium Industry Seminar Proceedings, October 22-23, 1980, Grand Junction, Colo.: U.S. Department of Energy Report GJO-108(80), p. 59-76.

Cameron, C.C., 1985, Uranium in Holocene deposits (abs.): 20th Annual Meeting Northeastern Section, The Geological Society of America, Abstracts with Programs 1985, v. 17, no. 1 , p. 10.

Canada Department of Energy, Mines, and Resources, Canada, 1977, Oil and natural gas resources of Canada, 1976: Ottawa, Report EP-77-1, 76 p.

Castor, S.B., Berry, M.R., and Siegmund, B.L., 1982, National uranium resource evaluation, Sandpoint quadrangle, Washington, Idaho, and Montana: U.S. Department of Energy Report PGJ/F-005(82), 77 p. 
Ellis, J.R., Harris, D.P., and Van Wie, N.H., 1975, A subjective probability appraisal of uranium resources in the state of New Mexico: U.S. Energy Research and Development Administration Report GJO-110(76), 97 p.

Energy Information Administration, 1985, Uranium industry annual 1984: Energy Information Administration DOE/EIA-047(84), 144 p.

Fleshman, B.R., 1982, National uranium resource evaluation, Spokane quadrangle, Washington and Idaho: U.S. Department of Energy Report PGJ/F-009(82), 25 p.

Ford, C.E., and McLaren, R.A., 1980, Methods for obtaining distributions of uranium occurrence from estimates of geologic features: U.S. Department of Energy Report GJBX-165(80), $121 \mathrm{p}$.

Fouch, T.D., and Ridgley, J.L., 1985, Uranium and thorium investigation in the U.S. Geological Survey (abs.) in Krafft, Kathleen, ed., USGS Research on Mineral Resources-1985, Program and Abstracts, V.E. McKelvey Forum on Mineral and Energy Resources: U.S. Geological Survey Circular 949, p. 63.

Harris, D.P., 1976, A survey and critique of quantitative methods for the appraisal of mineral resources: U.S. Energy Research and Development Administration Report GJBX-12(76), 624 p.

1977, Quantitative methods for the appraisal of mineral resources: U.S. Energy Research and Development Administration Report GJBX-14(77), 848 p.

1984, Mineral resources appraisal, mineral endowment, resources, and potential supply: Concepts, methods, and cases: Oxford, Clarendon Press, 445 p.

Harris, D.P., and Agterberg, F.P., 1981, The appraisal of mineral resources: Economic Geology, 75th Anniversary Volume, p. 897-938.

Harris, D.P., and Carrigan, F.J., 1981, Estimation of uranium endowment by subjective geological analysis-a comparison of methods and estimates for the San Juan Basin, New Mexico: Economic Geology, v. 76, no. 5, p. 1032-1055.

Hetland, D.L., and Grundy, W.D., 1977, Potential resources, in Uranium Industry Seminar Proceedings, October 26-27, 1977: U.S. Department of Energy Report GJO-108(77), p. 143-158.

Johnson, S.Y., Otton, J.K., and Macke, D.L., 1985, Geology of the north fork of Flodelle Creek drainage basin and surficial uranium deposit, Stevens County, Washington: U.S. Geological Survey Open-File Report 85-443, 38 p.

Joy Mining Company, 1983, Environmental impact statement for the proposed Joy Mining Company uranium mine and mill: Washington State Department of Social Health Services, $112 \mathrm{p}$.

Macke, D.L., Johnson, S.Y., and Otton, J.K., 1985, Sedimentology of a surficial uranium deposit on North Flodelle Creek, Stevens County, Washington (abs.): Society of Economic Paleontologists and Mineralogists Annual Midyear Meeting, August 11-14, 1985, Golden, Colo, Abstracts, v. II, p. 57-58.

Mathews, G.H., Jones, C.A., Pilcher, R.C., and D'Andrea, R.F., Jr., 1979, Preliminary recognition criteria for uranium occurrences: A field guide: U.S. Department of Energy Report GJBX-32(79), $41 \mathrm{p}$.

McCammon, R.B., Finch, W.I., Kork, J.O., and Bridges, N.J., 1986, Estimation of uranium endowment in the Westwater Canyon Member, Morrison Formation, San Juan Basin, New
Mexico, using a data-directed numerical method, in TurnerPeterson, C.E., Fishman, N.S., and Santos, E.S., eds., A basin analysis case study-the Morrison Formation, Grants uranium region, New Mexico: American Association of Petroleum Geologists, Studies in Geology No. 22, p. 331-355.

Mickle, D.G., and Mathews, G.W., 1978, Geologic characteristics of environments favorable for uranium deposits: U.S. Department of Energy Report GJBX-67(78), 250 p.

Nuclear Energy Agency and International Atomic Energy Agency, 1984, Uranium: Resources, Production and Demand: Paris, France, Organization for Economic Cooperation and Development, $348 \mathrm{p}$.

Otton, J.K., 1984a, Surficial uranium deposits in the United States of America, in Dennis Toens, project leader, Surficial uranium deposits, Report of the working group on uranium geology organized by the International Atomic Energy Agency: Vienna, Austria, Report IAEA-TECDOC-322, p. 237-242.

$1984 \mathrm{~b}$, Surficial uranium deposits in granitic terranes in the western United States (abs.): Geological Society of America Abstracts with Programs, v. 16, no. 5, p. 327.

Otton, J.K., and Culbert, R.R., 1984, Uranium in Holocene valleyfill, Carson Range, Nevada and California (abs.): Geological Society of America Abstracts with Programs, v. 16, no. 6, p. 616.

Otton, J.K., and Zielinski, R.A., 1985, Movement and concentration of uranium in young, organic-rich sediments, Stevens County, Washington: La Societe Francaise de Mineralogie et de Cristallographie et Le Centre de Recherches sur la Geolgie de l'Uranium, Program and Extended Abstracts, p. 49-52.

1986, Movement and fixation of uranium on organic matter in a late Quaternary uranium deposit, Stevens County, Washington (abs.), in Carter, L.M.H. ed., USGS Research on Energy Resources-1986, Pregram and Abstracts, The Second Annual V. E. McKelvey Forum on Mineral and Energy Resources: U.S. Geological Survey Circular 974, p. 49-50.

Otton, J.K., Zielinski, R.A., and Been, J.M., 1985, Uranium in Holocene valley-fill sediments, and uranium, radon, and helium in waters, Lake Tahoe-Carson Range, Nevada and California: U.S. Geological Survey Open-File Report 85-389, $30 \mathrm{p}$.

Schanz, J.J., 1975, Resource terminology: an examination of concepts and terms and recommendations for improvements: Palo Alto, Calif., Electric Power Research Institute, $116 \mathrm{p}$.

U.S. Department of Interior, 1980, Principles of a resource/ reserve classification for minerals: U.S. Geological Survey Circular 831, 5 p.

U.S. Department of Energy, 1980, An assessment report on uranium in the United States of America: U.S. Department of Energy Report GJO-111(80), 150 p., 6 microfiche.

1983, Statistical data of the uranium industry: U.S. Department of Energy Report GJO-100(83), 77 p.

Zielinski, R.A., Bush, C.A., and Rosholt, J.N., in press, Uranium series disequilibrium in a young surficial uranium deposit, northeastern Washington: Applied Geochemistry.

Zielinski, R.A., Otton, J.K., Wanty, R.B, and Pierson, C.T., in press, The geochemistry of water near a surficial, organicrich uranium deposit, northeastern Washington State: Chemical Geology. 


\author{
ME MORANDUM OF UNDERSTANDING \\ BETWEEN THE ENERGY INFORMATION ADMINISTRATION \\ U.S. DEPARTMENT OF ENERGY \\ AND THE U.S. GEOLOGICAL SURVEY \\ U.S. DEPARTMENT OF THE INTERIOR
}

\title{
INTRODUCTION
}

This Memorandum of Understanding (MOU) is an agreement between the Energy Information Administration (EIA), U.S. Department of Energy (DOE), and the U.S. Geological Survey (USGS), U.S. Department of the Interior (DOI). The MOU describes the implementation of an agreement for assistance from the USGS in the assessment of U.S. potential uranium resources in support of the EIA's work under Public Law 97-415 (January 4, 1983) to develop and provide information about the viability of the domestic uranium mining and milling industry.

\section{BACKGROUND}

With the close-out in Fiscal Year 1983 of the DOE's Uranium Resource Assessment (URA) Program at the Grand Junction Area Office (GJAO), including the National Uranium Resource Evaluation (NURE) Program, the uranium resource data collected under NURE and much of the data collected and compiled over the past 36 years at the GJAO have been passed to the USGS along with the responsibility for conducting follow-on work in potential uranium resource analysis. This transfer of data and responsibility is consistent with a budget decision made by the office of Management and Budget (OMB) (see action memorandum dated November 22, 1983, in the Appendix). The prior MOU between the DOE and the DOI required the development of a plan to ptovide support from the USGS for the continued appraisal of domestic potential uranium resources needed for the EIA's work in reporting the viability of the U.S. uranium industry under Public Law 97-415.

$\underline{\text { PURPOSE }}$

The purpose of this MOU is threefold: (1) to identify areas of support from the USGS for programs of the EIA relating to the ongoing study of the viability of the domestic uranium industry and the compilation of information on nuclear energy minerals for international program activities; (2) to define areas of cooperation between the EIA and the USGS concerning the mutual sharing of data on the uranium industry; and (3) to differentiate clearly the responsibilities of the agencies in the areas of cooperation and work discussed herein. 
The intent of this MOU is to comply with the requirement, stated in a previous MOU ${ }^{1}$ between the DOE and the DOI, that follow-on work, including potential uranium resource appraisal work required to meet objectives of the industry viability study, is to be conducted by the USGS consistent with the availability of its funds. The intent also is to describe the kinds and degrees of the USGS support foreseen for the EIA's programs. Specific details not addressed herein that relate to technical aspects of cooperation and conduct of the work shall be formalized in writing as necessary between the EIA and the USGS.

Under this agreement, there are to be no duplications by the EIA or the USGS of the functions vested in either organization and required by statute, nor is any abrogation of the provisions of the prior MOU signed by the secretary of the DOE and the secretary of the DOI intended.

$\underline{\text { SCOPE }}$

The scope of this agreement is limited to: (1) data developed at the GJAO under the URA program for the appraisal of domestic uranium endowment and potential uranium resources, including the computerized Uranium Resource Appraisal Data (URAD), the map data of potential uranium resource areas, and the supporting software for these two data bases; and (2) data for potential uranium resource appraisal purposes compiled from industry-supplied, company-confidential data aggregated to prevent disclosure of company-specific information and added to the URA data set by the EIA. Proprietary data on commercial activities of the uranium industry collected by the EIA through the U.S. Uranium Industry Annual Survey are expressly excluded from the purview of this agreement.

CONDUCT OF FOLLOW-ON POTENTIAL RESOURCE IPPRAISAL WORK

The principal support required from the USGS is 50 provide estimations of the conditional uranium endowment for use in the calculation of potential uranium resources using the DOE standard methodology. The DOE estimates of potential resources currently

1 "Memorandum of Understanding Energy and the Department of the Interior Implementing the Transfer of Responsibilities for Maintenance of Data Collected Under the National Uranium Resource Evaluation (NURE) Program and Providing for the Continuing Assessment of the Nation's Uranium Resources." The MOU was signed by the Secretary of Energy on November 30,1983 , and by the secretary of Interior on January 13, 1984 .

${ }^{2}$ Conditional uranium endowment is explained in the Appendix. 
are derived through a formally structured subjective-probability, geological-analogy procedure (the DOE standard methodology) which incorporates steps to minimize biases in the estimated totals. The estimates of U.S. potential uranium resources, covering as of January 1, 1984, over 700 individual estimates, are rooted in the standard methodology with its attendant assumptions which permit statistical analysis of these resource data.

Follow-on work to update these estimates should follow the standard methodology to permit ready entry of the new data into the DOE's automated, potential-resource data base and the subsequent use of all those data in analysis and reporting of U.S. resource totals as expected quantities (mean values) of corresponding aggregate probability distributions at specified confidence levels. In estimating the conditional uranium endowment, the USGS will modify the calculation of "F," the fraction of a favorable area believed to be underlain by uranium endowment, so that the geological data and judgments of the USGS are mathematically described and verified to the satisfaction of both the EIA and the USGS consistent with the standard methodology. This procedure will assure the integrity of the DOE's URA data set, the USGS parameters for uranium endowment, and the reliability/comparability of future published U.S. uranium resource estimates. The use of the standard methodology and existing computerized procedures also will provide the EIA with access to the most recent potential resources data as stipulated in the previous MOU (see Footnote 1 on page 1).

Computerized resource data files and programs, which were developed jointly by the Oak Ridge National Laboratory and the GJAO for the computation of uranium endowment and potential resources, are operational, and these procedures can be used in the follow-on resource appraisal work. A process will be developed through discussions with the USGS whereby its personnel will be able to use these resource data and computational procedures interactively as an aid in developing their own resource estimates.

A. Selection of Potential Resources Study Areas

The EIA and the USGS by mutual agreement shall compile annually a slate of prospective potential resource areas, wherein it is deemed that additional or new geological studies are warranted based on the availability of new data or on reinterpretations of existing data. The slate of areas for a given work year should be prepared sufficiently early to permit geological studies in the areas to be completed, estimations of the areas' uranium resources completed, and the resulting new resource data entered in the DOE data files during the same work year. Major emphasis shall be given to the selections of uranium resource areas for which studies likely will result in significant modifications in the nation's uranium resource totals, i.e., by increasing or 
decreasing resource estimates by 500 tons $\mathrm{U}_{3} \mathrm{O}_{8}$ or more per area. Exceptions would be areas not previously assessed and areas currently assigned a small potential resource that, based on current analysis, possibly should be deleted.

B. Access to the DOE Potential Resources Data Bases

The DOE potential resources data currently are collected into two computerized data bases. The assessment data base contains information on regional totals for uranium reserves in the 20 U.S. resource regions and the approximately 700 potential resource assessments spanning the DOE classes of probable, possible, and speculative. Access by the USGS to this data base, formally named the Uranium Resource Appraisal Data (URAD), and its supporting software shall be provided by the EIA. The map data base contains labels and digitized areas data for both assessed (potential resource) areas and unassessed areas delineated by the field geologist who studied these areas. Under the current plan for follow-on resource appraisal work, the map data base and supporting automated procedures will be archived in the EIA's computer facility for possible future applications. The map data, program procedures, and compilations of maps of potential resources data shall be available to the USGS.

\section{Derivation of Potential Resource Estimates}

The standard methodology shall be utilized in deriving estimates of potential resources from new conditional uranium endowment data to assure their comparability with the DOE existing potential resource estimates and that the resulting data can be aggregated to form national resource totals.

\section{Modifying the DOE Potential Resources Data Files}

Proposed changes to add new resource data or to update existing resource data shall be approved by designated EIA and USGS staff prior to the adoption of the changes. This arrangement will prevent unauthorized modifications and assure the entry of correctly encoded data. Standard NURE codes shall be used to enter new data into the data bases. A manual of current listings of the standard DOE codes shall be provided by the EIA. The reporting of new data on conditional uranium endowment and backup information (Parts I, II, and III on the DOE UR-85 data input form, January 1, 1984; see the Appendix, Figure 1) developed by the USGS shall consist of the entry of proper data into the assessment (URAD) data base. A manual covering the use of the as sessment data files shall be provided by the EIA. The adding of new uranium endowment data shall be completed at specified times during the year so that timely, current listings 
of the nation's uranium potential can be obtained in support of the EIA reports mandated by Public Law 97-415 and to meet other needs. A schedule of times for adding the new data will be developed and approved jointly by the EIA and the USGS.

For new or revised estimations of uranium endowment, a map(s) showing the outline for each favorable area(s) (corresponding to the parameter "A" in the endowment equation, $\mathrm{Ue}_{\mathrm{e}}=\mathrm{A} \cdot \mathrm{F} \cdot \mathrm{T} \cdot \mathrm{G}$ ) shall be provided by the USGS to the EIA to permit the compilation of an updated map of U.S. resource areas for use by the EIA, USGS, and other agencies.

E. Classification of the EIA Potential Resource Estimates

The DOE classification scheme for potential resources shall be used for categorizing new and revised resource estimates. This classification encompasses the classes of probable, possible, and speculative potential uranium resources and the corresponding definitions as published in the DOE's report GJO-100(83) ${ }^{3}$ and the report GJO-111(80). In addition, probable potential resources will be further delineated into two subcategorigs, designated as Estimated Additional Resources (EAR) - I and -II. Standardization to this classification scheme will assure comparability between future published totals, those developed under the NURE Program, and those required under section G below.

F. Sharing of Company-Confidential Data

Many of the company-specific uranium resource data that were received by the EIA under the transfer of the URA function from the GJAO are proprietary, company-confidential data. Certain of these company-specific data will be useful to the USGS in conducting its work on appraising uranium endowment. Similarly, certain confidential data held by the USGS might be useful in the conduct and reporting of the EIA work. It is the intent of this agreement that only the URA data, as described in the SCOPE section above, and the uranium resources data held by the USGS shall be shared by the DOE and the USGS.

${ }^{3}$ U.S. Department of Energy, Statistical Data of the Uranium Industry, GJo-100(83), Grand Junction, Colorado, Grand Junction Area Office, U.S. Department of Energy, 1983, p.15.

${ }^{4}$ U.S. Department of Energy, An Assessment Report on Uranium in the United States of America, GJo-111(80), Grand Junction Area Office, U.S. Departmicnt of Energy, 1980, p.21.

${ }^{5}$ Nuclear Enorgy Agency and International Atomic Energy Agency, Uranium: Resources, production and Demand, Organization for Economic Cooperation and Development, Paris, France, 1984. 
1. Data shared between the DOE and the USGS which are marked as company confidential are to be considered as proprietary and are for official, programmatic use only, and they shall be divulged to a party outside of the Federal Government only with the written consent of the company/individual which provided the data, or in accordance with the law.

2. Before publishing or disseminating any aggregations based on the data transmitted under this agreement, each agency agrees to consult with and obtain the concurrence of the agency that originated the data on which the aggregation is based. Such aggregated data, which are based on company-confidential data, may be released only when they are in such a format that the identity of any portion of the data attributable to any specific firm is not revealed.

3. In all cases, care shall be given to the assurance that there are adequate physical and procedural safeguards to protect the proprietary nature of any data shared between the EIA and the USGS from inadvertent disclosure.

4. Eách agency shall refer for response any request for data transmitted under this agreement to the agency that originated such data, including any request from the General Accounting Office, the Congress or any duly established committee of Congress, or other Congressional agency.

5. Upon notification that a Court order requiring disclosure of the data transmitted under this agreement will be or has been sought, the USGS agrees to: (a) consult with the EIA to determine whether arguments against disclosure of the data should be presented to the court, in the first instance, and, in any event, seek a protective order that preserves the confidentiality and limits the use of further disclosure of the proprietary data; and (b) afford the EIA an opportunity to review and comment on the terms of the proposed protective order. In the event that the court issues an order requiring disclosure of the data, the USGS will provide the EIA and the originators of the data with 10 days written notice prior to disclosure, or, alternatively, as much advance notice as can reasonably be provided under the circumstances. At the time of such disclosure, the USGS will advise those persons receiving the data, that the data were obtained by the EIA from respondents for statistical purposes and that the EIA and the respondents consider the data to be proprietary business data. The EIA, in turn, agrees to comply with these procedures regarding court or ders affecting any data it receives under this agreement from the USGS. 
Nuclear energy minerals pertinent to international program activities are primarily uranium and secondarily thorium. The resources of these minerals are reported every two years by the Organization for Economic Cooperation and Development's Nuclear Energy Agency (NEA) and the International Atomic Energy Agency (IAEA) in a joint report, commonly called the Red Book, entitled "Uranium: Resources, Production and Demand." The Red Book contains text and statistics on U.S. uranium resources, production, and demand. It also contains a section on U.S. resources of thorium.

In the past, the DOE has provided the necessary information on U.S. uranium resources for the Red Book publication, and the USGS has contributed some geologic data on uranium and nearly all of the geologic and resource data on thorium. In the future, compilations of information on uranium and thorium will be performed cooperatively by the DOE and the USGS under the following arrangement:

(a) nongeological data on uranium resources will be supplied by the DOE,

(b) geological information on uranium will be supplied by the USGS,

(c) all information on thorium resources will be supplied by the USGS, and

(d) the submission of all final U.S. data and information on uranium and thorium will be coordinated by the DOE.

To ensure consistent and useful information for the Red Book, both agencies will have a representative on the NEA/IAEA Working Party on Uranium Resources with the DOE representative serving as the head of the delegation, while the USGS and the U.S. Bureau of Mines would participate in all international activities related to uranium geology, for example in the work of the Joint Group of Experts on Research and Development in Uranium Exploration Techniques and the Working Group on Uranium Extraction. The DOE will continue to represent the United States at the joint NEA/IAEA Steering Group on Uranium Resources in dealing with the $\mathrm{NEA}$ and the IAEA.

APPLICATION OF ALTERNATE POTENTIAL RESOURCES DERIVATION AND CLASSIFICATION

In the preceding sections of this MOU, general procedures have been described that will permit the continued derivation of 
annual estimates of U.S. potential uranium resources through application of the DOE methodology with new data on conditional uranium endowment from the USGS, the use of the URAD data files and the supporting computerized procedures for data storage, computation, and retrieval. Justification for this approach is given above.

The proposed approach should be viewed as an interim one, because, with the close-out of the NURE program at the GJAO and the shifting of the responsibility for the study of uranium deposits and the determination of uranium endowment from the DOE to the USGS, a different set of emphases and concerns have emerged relative to the carrying forward of a U.S. potential resource appraisal effort under a new, practical, and viable program. The development and application of resource-estimation procedures that incorporate current knowledge and

state-of-the-art technology from mathematics, geology, and other disciplines to construct reliable appraisals of undiscovered natural resources is a continuing goal. The work now is to be carried forward with fewer monetary and personnel resources than were available during the NURE program.

The development and application of modified or alternate uranium endowment and resource appraisal procedures shall be encouraged under this MOU to ensure that state-of-the-art techniques and knowledge are used in the follow-on work. The feasibility of incorporating new procedures into the standard methodology shall be decided jointly by the EIA and the USGS. In a similar manner, the investigation of modified or alternative resource classification schemes shall be encouraged.

MANAGEMENT ARRANGEMENTS AND REVIEW OF FOLLOW-ON RESOURCE APPRAISAL WORK

Direct communication between the DOE and the USGS program officials designated as responsible for the performance of the cooperative work under this MOU is anticipated. Letters between the agencies describing project plans in appropriate detail will serve as program documentation for work arrangements as may be required in the implementation, coordination, and conduct of the work.

An oversight committee, consisting of designated officials from each agency, shall meet periodically--quarterly or less

frequently as required--to review accomplishments and the status of the follow-on work, and to discuss program guidance and the adequacy of the work in meeting the needs of the respective agencies' programs. 
A. Public Information Coordination

Upon receipt of any request made under the Freedom of Information Act (5 U.S.C., paragraph 552(b)), each agency shall respond with regard to that portion of the data that was originated by that agency. Decisions concerning the disclosure of any information developed jointly by the USGS and the EIA shall be determined jointly between appropriate representatives of the EIA and the USGS.

B. Amendment and Termination

This MOU may be modified or amended by written agreement between the EIA and the USGS, and it may be terminated by mutual agreement of the EIA and the USGS or unilaterally by either party upon a 60-day written notice to the other.

C. Effective Date

This MOU is effective upon the date of final signature.

U.S. GEOLOGICAL SURVEY

U.S. DEPARTMENT OF THE INTERIOR

\section{Dallas L Pock}

(Signature)

(Title)

\section{SEP 201984}

(Date)
ENERGY INFORMATION

ADMINISTRATION

U.S. DEPARTMENT OF ENERGY

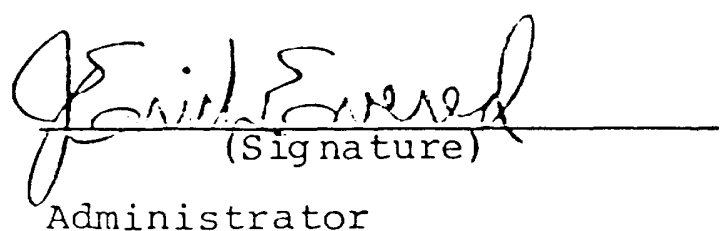

Energy Information Administration

( $\mathrm{Tit}$ le)

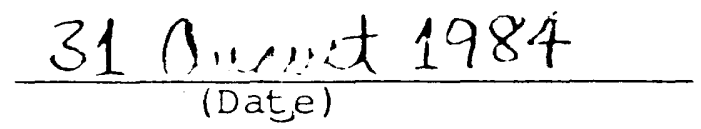



쥬

蛋

당

亩

瞫

m

Q

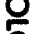

8

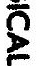

叻

음

గ̂̉

5

8 